\title{
Pleisztocén folyóvízi kavics a Villányi-hegységben
}

\author{
Szujó Gábor Lajos ${ }^{1}$, Sebe Krisztina ${ }^{1}$, SiPos György², PozsGai Emília ${ }^{1}$ \\ 'Pécsi Tudományegyetem, Földtani és Meteorológiai Tanszék, 7624 Pécs, Ifjúság ú. 6; sujo21 @ gamma.ttk.pte.hu, sebe@ gamma.ttk.pte.hu, \\ emily.pozsgai@gmail.com, \\ ${ }^{2}$ Szegedi Tudományegyetem, Természeti Földrajzi és Geoinformatikai Tanszék, 6722 Szeged, Egyetem u. 2-6; gysipos@ geo.u-szeged.hu
}

\section{Pleistocene fluvial gravel in the Villány Hills (SW Hungary)}

Abstract

In the Villány Hills, the southernmost exposed basement block of Hungary, Cenozoic rocks have been known to be represented mostly by Late Pliocene - Quaternary terrestrial sediments, red clays and loess. Cleaning of a classic exposure, the cable-car cut on Templom Hill in the village of Villány, at the eastern termination of the Villány Hills, revealed a hitherto unknown Quaternary deposit overlying the Mesozoic basement rocks, which may add important information to the Cenozoic evolution history of the area. This paper aims at describing this deposit, identifying its sedimentary environment and concluding on the palaeogeographic conditions.

The strongly tilted Mesozoic succession is overlain by coarse gravel with a sand interbed, then after an erosional unconformity by slope loess with gravel seams. Clast lithologies indicate that the gravel has a local origin. Its source rocks are Middle Triassic Templomhegy Dolomite, Upper Triassic Mészhegy Sandstone, Lower Jurassic Somssichhegy Limestone and Pliocene-Quaternary cavity-filling red clay and calcite, all occurring within Templom Hill and along the northern side of the Villány Hills. The heavy mineral assemblage of the sand interbed in the gravel is similar to that of the directly underlying Mészhegy and Somssichhegy Formations. The wide range of the rounding of clasts (poor to good) also points to short transport. The age of the gravel is not older than Pleistocene based on the Early Pleistocene age of the cavity-filling red clays in the area; the sand interbed is older than $400 \mathrm{ka}$ according to OSL dating results. Based on the above points, the gravel can be interpreted as a fluvial terrace, a deposit of a watercourse flowing in the area during the Early and/or Middle Pleistocene. This watercourse was probably the ancestor of the modern Villány-Pogány Stream, flowing along and eroding the northern margin of the Villány Hills. Due to the slow uplift of the basement, the stream incised, the gravel got exposed and eroded. A gentle-sloped small valley incised into it and became filled up during the Riss glaciation (MIS 6) with loess and sandy-gravelly sheet wash deposits. The uplift rate of the area in the younger Quaternary did not exceed $\sim 0,05 \mathrm{~mm} /$ year.

Keywords: Pleistocene, fluvial terrace, uplift rate, OSL, post-IR IRSL, heavy mineral

Összefoglalás

A Villányi-hegységben eddigi ismereteink szerint a kainozoos képződményeket elsősorban késő-pliocén-kvarter szárazföldi üledékek, vörösagyagok és lösz képviselik. A villányi Templom-hegy siklóbevágásának közelmúltbeli letisztítása eddig ismeretlen kvarter képződményt tett hozzáférhetővé, amely fontos adalékot jelenthet a Villányi-hegység kainozoos fejlődéstörténetéhez. A cikk célja a mezozoos rétegekre települt fedőképződmények leírása, képző́dési körüiményeinek, valamint korának meghatározása és ősföldrajzi viszonyainak felvázolása.

A kibillent alaphegységi rétegsorra homokbetelepüléses durva kavics, majd eróziós határral kavicszsinóros aleurit települ. A durva kavics a kőzetanyagok vizsgálata alapján a közvetlen közelből származik, a forráskőzetek nagy része azonosítható a Villányi-hegység északi részén található, főleg alaphegységi (Csukmai Formáció Templomhegyi Dolomit Tagozata, Mészhegyi Homokkő és Somssichhegyi Mészkő Formáció), kis részben fiatalabb kőzettípusokkal (üregkitöltő vörösagyag és kalcit). A kavicsba települő homok nehézásvány-összetétele a közvetlen fekü felső-triász Mészhegyi és Somssichhegyi Formációval rokonítható. Szintén rövid szállítási távolságra utal a kavicsok vegyes, gyenge-jó koptatottsága. A kavicsösszlet kora a környéken pleisztocén korú üregkitöltő kalcit és vörösagyag anyagú kavicsok alapján pleisztocénnél nem idősebb; a betelepülő homok OSL módszerrel meghatározott kora több mint 400 ezer év. A fentiek alapján a kavicsösszletet egy, a késő-pleisztocénnél korábban már létezố vízfolyás üledékeként, folyóvízi teraszként értelmezhetjük. Ez a folyóvíz a mai Villány-pogányi-vízfolyás ôse lehetett, amely a hegység északi előterében, annak lábánál haladva érinti az azonosított forráskőzeteket. A hegység lassú emelkedésével a vízfolyás 
bevágódott, a kavicstest szárazra került és erodálódott, kis, lapos völgy vágódott bele, majd töltődött ki a riss (MIS 6) során lejtőlösszel és felületi lemosással szállítódó homok-kavics méretú törmelékkel. A terület emelkedési üteme a fiatal negyedidőszakban legfeljebb $\sim 0,05 \mathrm{~mm} / \mathrm{év}$ lehetett.

Tárgyszavak: pleisztocén, folyóvízi terasz, emelkedési ütem, OSL, post-IR IRSL, nehézásvány-vizsgálat

\section{Bevezetés}

Hazánk legdélebbi hegységében, a Villányi-hegységben az alaphegységet mezozoos kőzetek alkotják. Eddigi ismereteink szerint a kainozoos képződményeket a hegységben széles területen előforduló késó-pliocén-kvarter szárazföldi üledékek, elsôsorban vörösagyagok és lösz képviselik (RAKUSZ \& STRAUSZ 1953). Ugyan a peremi részeken és az előtérben néhány helyen kis foltokban írtak le kôzettani analógia alapján miocén korúnak tekintett homokokat (LÓCZY 1912, RAKUSZ \& STRAUSZ 1953). Ezek kora a legtöbb esetben ősmaradványok híján bizonytalan. Egyes esetekben koruk tisztázott és bizonyítottan nem miocén, mint például a villányi Templom-hegy „mediterrán”-ként leírt homokja (LócZy 1912), mely a felsô-triász Mészhegyi Formációba sorolható (ŐsI et al. 2013, VöRÖs 2010). Az üledékek hiányából következóen ismereteink a hegység kainozoos fejlődéstörténetéról igen szúkösek.

A hegység földtanilag kétségkívül legismertebb helyszíne keleti elvégzôdése, a villányi Templom-hegy (1. áb$r a)$, amelynek mind mezozoos összlete, mind kvarter, gerincesmaradványokban gazdag vörösagyagjai nemzetközi hírúek (részletesen 1. VÖRÖS 1990, 2010; PAZONYI 2009 és hivatkozásaik). A hegy tetején kialakított nagy kőfejtő kitermelt anyagát az úgynevezett siklóbevágás alagútján át szállították a vasútállomás felé; ez az alagút később beomlott (LóCZY 1945, VÖRÖs 2010). A siklóbevágás feltárását, mint fontos alapszelvényt (RÁLISCHNÉ FELGENHAUER
1985), többször kitisztították, legutóbb 2012-ben a Pécsi Tudományegyetem Földtudományok Doktori Iskolája, ennek eredményeképp jelenleg 30 méteres hosszon vizsgálhatók a kőzetek (ỐsI et al. 2013). A letisztított feltárásban látható volt, hogy a triász és jura rétegekre diszkordánsan bizonytalan korú és eredetú törmelékes üledékek települnek. Ezek vizsgálata még nem történt meg; a korábbi írások csak mellékesen, kvarter üledékként vagy lejtőtörmelékként említik (VöRös 2010), mivel a legtöbb kutatás a mezozoos rétegsorra irányult. Közelebbi vizsgálat során arra derült fény, hogy a feltárás eddig ismeretlen kvarter képződményt tett hozzáférhetővé, amely fontos adalékot jelenthet a Villányi-hegység kainozoos fejlódéstörténetéhez. Jelen munka célja a siklóbevágás kainozoos összletének leírása, a durvatörmelékes rétegsor anyagának vizsgálata, a lehetséges forráskôzetek azonosítása, valamint az üledék korának meghatározása. Ezek alapján kísérelhetô meg a képződés körülményeinek körvonalazása és az ősföldrajzi környezet és fejlődéstörténet felvázolása, beleértve a tektonikai vonatkozásokat.

\section{Vizsgálati terület}

A vizsgált feltárások a villányi vasútállomástól délre, a Templom-hegy északi oldalán találhatók (2. ábra). A siklóbevágás [EOV 603479; 59171, 2. ábra 1] a nagy kőfejtóbe

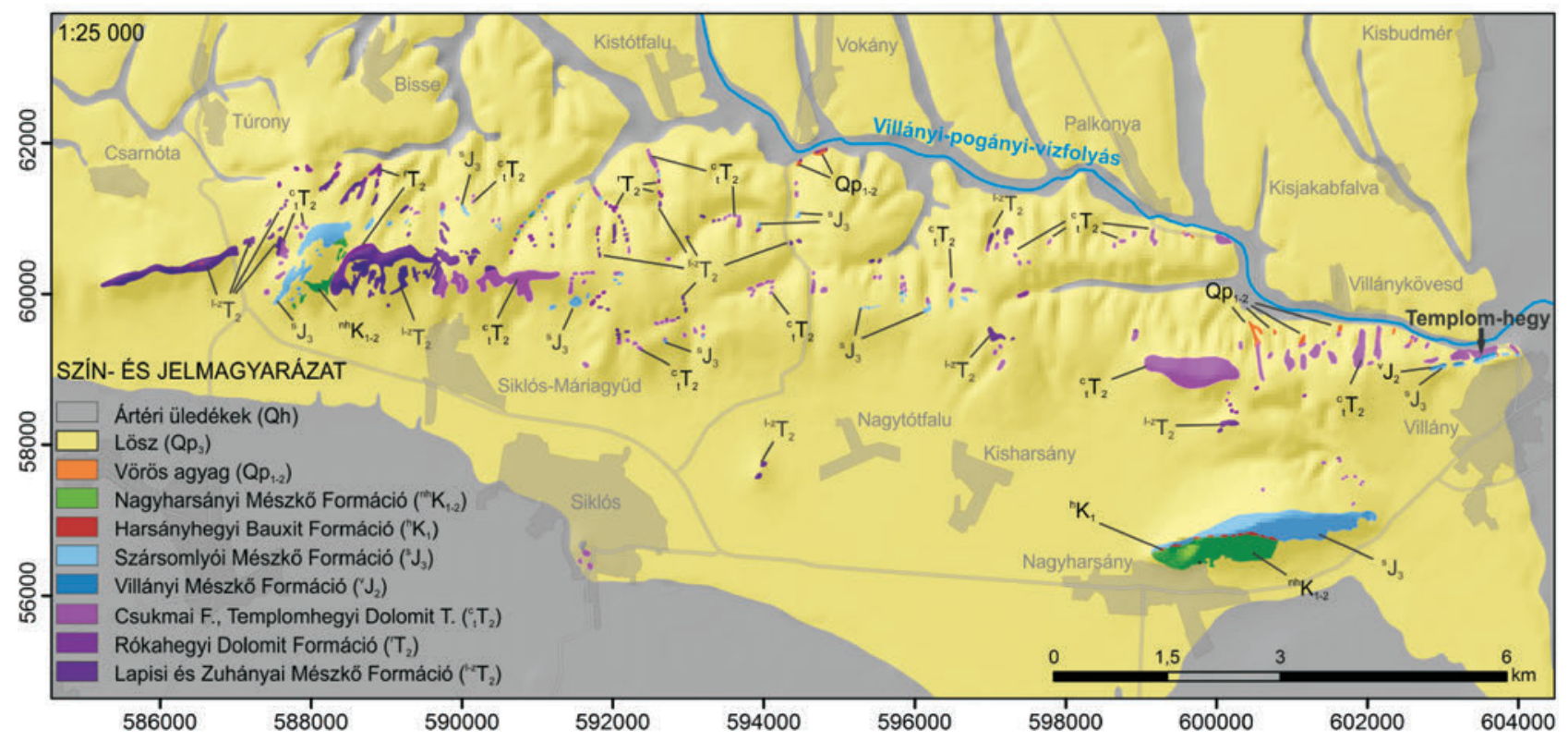

1. ábra. A Villányi-hegység földtani térképe (CHIKÁN et al. 2005 alapján)

Figure 1. Geology of Villány Hills (after CHIKÁN et al. 2005) 


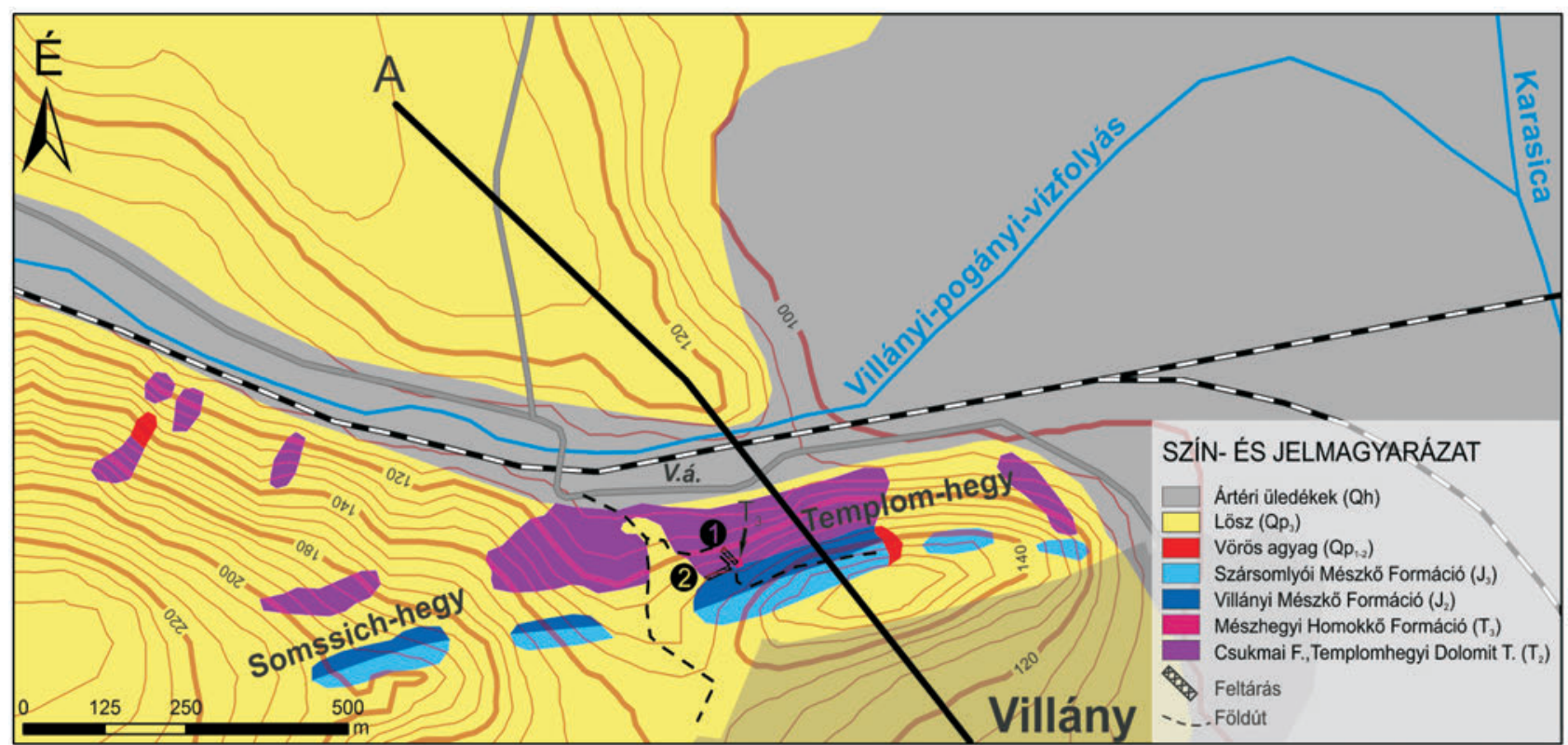

2. ábra. A templom-hegyi feltárások helyszínrajza. 1: siklóbevágás; 2: a kőfejtỏ északi falának feltárása; A: a 10. ábra szelvényének nyomvonala Figure 2. Location of exposures at Templom Hill. 1: cable-car cut; 2: northern wall of the big quarry; A: cross-section in Fig. 10

vezető bányavasút nyomvonala mentén, és másik feltárás [EOV 603458; 59154, 2. ábra 2] attól délnyugatra, a kőfejtő északi falában található. A Templom-hegy alaphegységi része középsô-triásztól alsó-juráig terjedô karbonátos és törmelékes rétegsort tár fel, amely dél felé a nagy kőfejtőben középső- és felső-jura karbonátokkal folytatódik (RÁLISCHNÉ FelgenHAUER 1985, VöRÖS 1990). Ebbe a jura mészkőösszletbe mélyülnek a vörösagyaggal és durva pátos, fenn-nőtt barlangi kalcittal kitöltött karsztos üregek, melyek kora- és középsô-pleisztocén gerincesmaradványokat tartalmaznak (PAZONYI 2009 és hivatkozásai). A tetôket a hegység nagy részéhez hasonlóan itt is lösz fedi, amely nem típusos, hanem „lejtôlösz” (lejtôn lerakódott lösz — Lovász \& WEIN 1974).

\section{Módszerek}

A terepi munka az üledékes egységek leírásából, a kavicsanyag makroszkópos vizsgálatából, valamint a kavicsanyag elterjedésének tisztázása és a földtani és geomorfológiai környezet megismerése céljából, terepbejárásokból állt. A vizsgált üledéktest lehetséges forrásterületét a kavicsanyag kôzettani, valamint a homok mikromineralógiai vizsgálatával, az ôsföldrajzi környezetet a geomorfológiai viszonyok elemzésével próbáltuk meghatározni.

A kavicstestbe települő homokból nehézásvány-vizsgálatra vett mintából (helye a 3. ábrán) a 100-200 ㅆ-es nehézásványfrakciót bromoformos $\left(2,85 \mathrm{~g} / \mathrm{cm}^{3}\right)$ eljárás útján a Magyar Állami Földtani és Geofizikai Intézet laboratóriumában különítették el. Közel 500 db nehézásvány múgyantás szemcsepreparátumon történő binokuláris és polarizációs mikroszkópos vizsgálatát végeztük el.

OSL kormeghatározás céljából két pontról gyújtöttünk mintát, ezek sztratigráfiai elhelyezkedését a 3. ábra mutatja. A módszer alapjairól magyar nyelven pl. NovothnY \& ÚsHÁZY (2000) nyújt áttekintést, a mérések segítségével az üledékek utolsó napfényre kerülésének idôpontja adható meg. Az 1. jelú minta (laboratóriumi archiválási száma: 1010) a terepi megfigyelések alapján középszemú homok, a 2. jelú minta (laboratóriumi archiválási száma: 1011) homokos lösz volt. Ennek megfelelően a két mintát eltérő laboratóriumi feltárásnak vetettük alá. Az 1. minta esetében a 90-150 um-es (durva szemcsés eljárás), a 2. minta esetében pedig a 4-11 $\mu$ m-es (finom szemcsés eljárás) frakciót választottuk le szitálás, illetve ülepítés segítségével. Ezt követôen eltávolítottuk a minták karbonát- és szervesanyagtartalmát $10 \% \mathrm{HCl}$ és $10 \% \mathrm{H}_{2} \mathrm{O}_{2}$ többszöri alkalmazásával. A durva szemcsés frakción nehézfolyadékos (nátriumheteropolivolframát - LST Fastfloat) ásványszeparációt végeztünk. Ennek kapcsán a kvarc $\left(2,62-2,68 \mathrm{~g} / \mathrm{cm}^{3}\right)$ és a Kföldpát $\left(<2,58 \mathrm{~g} / \mathrm{cm}^{3}\right)$ alkotókat választottuk le. A kvarcszeparátumot $40 \%$ HF felhasználásával 45 percen át marattuk, az esetleges földpát szennyezők, valamint a kvarcszemcsék külső, az alfa sugárzási komponens által átjárt 5$10 \mu \mathrm{m}$-es rétegének eltávolítása céljából. Többszöri desztillált vizes átmosást követôen az esetleges fluorid maradványok eltávolítása érdekében 10\% HCl-t alkalmaztunk. A K-földpát szeparátumot nem marattuk, így ebben az esetben késóbb számolni kellett az alfa komponens hatásával is. A 2. minta esetében a teljes polimineralikus anyag került a mérés során felhasználásra, így ennek esetében további maratás nem történt, a savas kezelést követően acetonos ülepítés segítségével (6 cm-es aceton oszlopban 2 min és $20 \mathrm{~min})$ újból leválasztottuk a 4-11 $\mu$ m-es frakciót. A mérésekhez a durvaszemcsés szeparátumokat acél, a finomszemcsés polimineralikus mintát pedig alumínium hordozókorongokra vittük fel. 

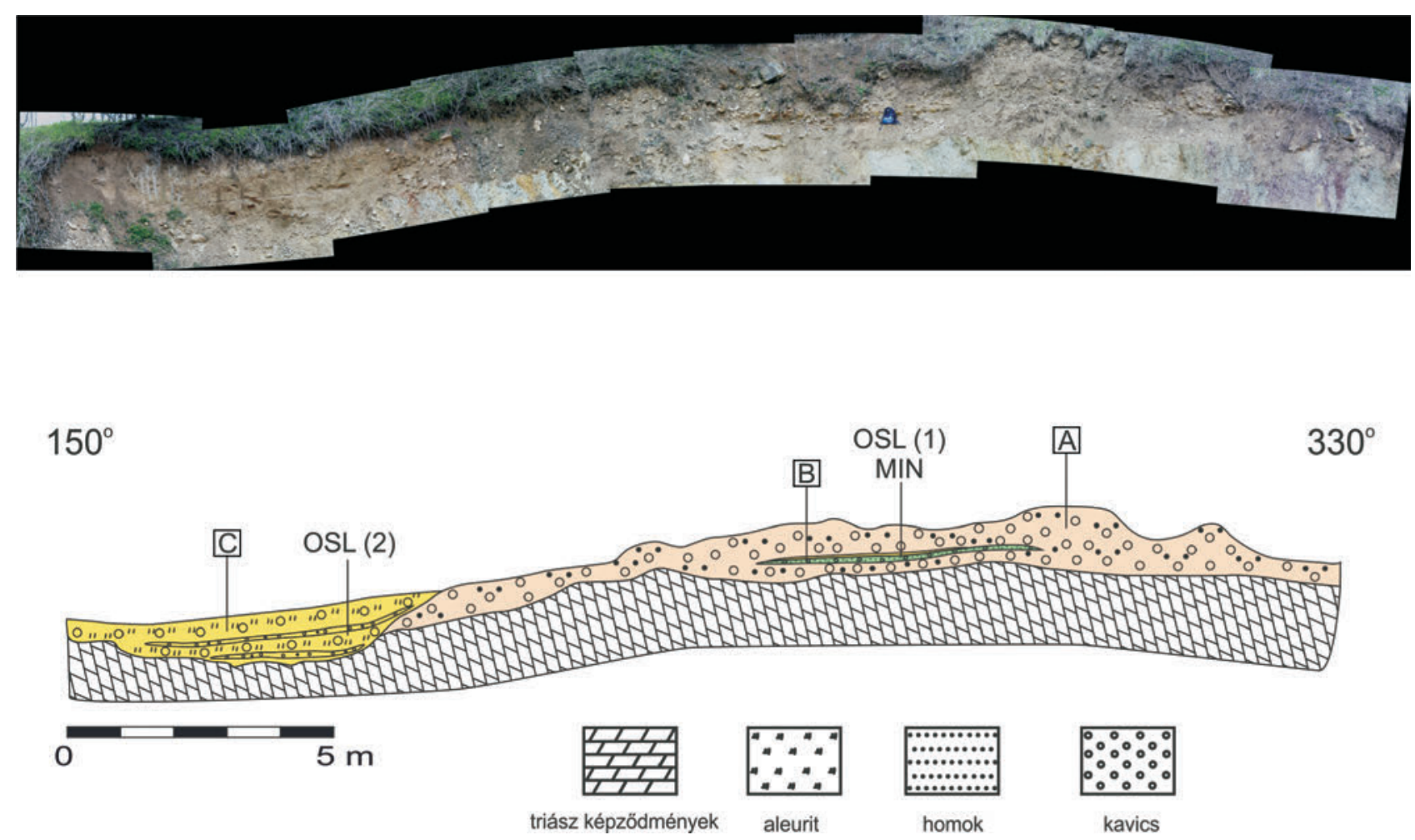

3. ábra. A feltárás litológiai egységei. A: homokos kavics; B: kavicsos homok és aleurit; C: kavicsbetelepüléses aleurit; OSL: minta lumineszcens kormérésre; MIN: minta ásványtani vizsgálatra

Figure 3. Lithological units of the exposure. A:sandy gravel;B:gravelly sand and silt; C: silt with gravel seams;OSL: sample for luminescent age measurement; MIN: sample for mineralogical investigation

Az OSL kormeghatározás során a kort két paraméter hányadosából lehet számítani: 1) a vizsgált üledék szemcséiben az eltemetődés óta elnyelt összes radioaktív dózis (paleodózis, illetve az ezzel ekvivalens egyenérték dózis), valamint 2) a minta által egységnyi idó alatt elnyelt dózis (dózisteljesítmény vagy dózisráta). Az egyenérték dózis meghatározásához szükséges lumineszcens méréseket a durvaszemcsés 1. minta esetében RIS $\varnothing$ TL/OSL DA-20, a finomszemcsés 1. minta esetében RISØ TL/OSL DA-15 típusú múszeren végeztük el. Előbbi múszer béta sugárforrása $\left({ }^{90} \mathrm{Sr} /{ }^{0}{ }^{0} \mathrm{Y}\right)$ acél hordozókorongra kalibrálva $\left({ }^{90} \mathrm{Sr} /{ }^{90} \mathrm{Y}\right): 0,125 \pm 0,002 \mathrm{~Gy} / \mathrm{s}$ dózisteljesítménnyel utóbbié pedig alumínium hordozókorongra kalibrálva 0,078 $\pm 0,002 \mathrm{~Gy} / \mathrm{s}$ dózisteljesítménnyel rendelkezett. A lumineszcens jelek detektálása kvarc OSL esetében Hoya U-340, K-földpát IRSL esetében Schott BG-39 és BG-3 szúrőkön keresztül történt.

A lumineszcens mérések alapvetően az egymintás regenerációs eljárás (SAR - single aliqout regeneration) alapján (MURRAY \& WiNTLE 2000), illetve annak módosított változatait felhasználva történtek. A durva szemcsés 1. minta esetében a kvarcszeparátum mérése során a SAR szekvenciát termális tisztítással (hot-bleach) egészítettük ki (WinTLE \& MurRAY 2006), míg a K-földpát kapcsán az ún. post-IR IRSL ${ }_{225}$ valamint a post-IR IRSL ${ }_{290}$ SAR protokollt alkalmaztuk, melyeket kifejezetten idős minták mérésére dolgoztak ki (THOMSEN et al. 2008, ThiEL et al. 2011). A finomszemcsés 2 . esetében egyrészt az ún. double-SAR protokollt, mely lehetővé teszi a polimineralikus minták kvarckomponensének elkülönített mérését (ROBERTS 2007), valamint a post-IR IRSL $_{290}$ protokollt alkalmaztuk. A vizsgálatok részeként előmelegítési, és dózis-visszamérési teszteket is végeztünk. Ezek a választott protokoll alkalmazhatóságát, megbízhatóságát tárják fel. A minták a tesztek során megfelelóen viselkedtek. A dózisokra adott, érzékenység-változással korrigált lumineszcens intenzitások értékeihez exponenciális, illetve exponenciális + lineáris függvényeket illesztettük. Tekintettel arra, hogy a várakozások alapján igen idős mintákról volt szó, minden esetben meghatároztuk a dózis-lumineszcens válaszgörbék töréspontjára jellemző dózisértéket $\left(\mathrm{D}_{0}\right)$. Elviekben ennek kétszerese jelzi a mérések határát, ami hozzávetőleg a telítettségi lumineszcens intenzitás 85\%-nak felel meg (WinTLE \& MuRRAY 2006). Másképp fogalmazva telítettség esetén a $2 \times \mathrm{D}_{0}$ érték alapján megadható az adott mintára vonatkozó minimum kor. A földpátokon végzett IRSL mérések kapcsán további problémát okozhat a természetes lumineszcens intenzitás spontán fakulása, valamint a nem megfelelô kioltódás az üledékképződés során. Mivel egyrészt a minták a dózistelítettség határán mozogtak, másrészt a post-IR-IRSL ${ }_{290}$ protokoll igen stabil, fakulás által alig érintett IRSL jelek mérését teszi lehetővé (MuRRAY et al. 2014) ezért ezek a tényezók elhanyagolható mértékben befolyásolták a kapott eredményeket, s így ezek pontos meghatározásával nem foglalkoztunk.

A dózisteljesítmény meghatározásához a minták környezetéből gyújtött üledéken végeztünk gamma spekt- 
roszkópiás méréseket. Az üledéket szárítást és porítást követôen $550 \mathrm{~cm}^{3}$-es marinelli edényekbe töltöttük. A méréseket Canberra típusú, $3 \mathrm{keV}-2 \mathrm{MeV}$ tartományban alkalmazható XtRA HPGe koaxiális detektorral ellátott múszeren végeztük a Rn egyensúly beálltát követően. A vizsgált radioaktív elemek (U, Th, K) aktivitás koncentrációiból ADAMIEC \& AITKEN (1998) konverziós faktorai alapján számítottuk a különböző sugárzási komponensekre vonatkozó dózisteljesítmény-értékeket. A száraz mintára

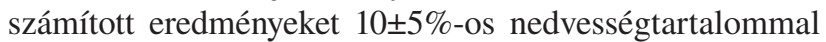
korrigáltuk. Mivel az 1. minta gyújtési helyén a homokréteg vastagsága mindössze $10 \mathrm{~cm}$ volt, ezért a gamma dózisteljesítményt jelentôsen befolyásolta a befoglaló kavicsos összlet, így ennek hozzájárulását külön is meghatároztuk. A K-földpát szemcsék (1. minta) esetében a külső környezeti dózisteljesítmény mellett belső dózisteljesítménnyel is számolni kell, ehhez HuNTLEY \& BARIL (1997) alapján $12,5 \pm 0,5 \%$-os K-tartalmat vettünk alapul. Mindemellett a külső réteg maratásának hiányában a számított béta és gamma dózisteljesítményt $0,050 \pm 0,025 \mathrm{~Gy} / \mathrm{ka}$ alfa dózisteljesítménnyel növeltük. A finomszemcsés 2. minta kapcsán a környezeti alfa sugárzás hatékonyságát a kvarcfrakció esetében $\mathrm{a}=0,06 \pm 0,02$, a földpát frakció esetében $0,08 \pm 0,02$ értékúnek vettük (MurRAY et al. 2014, SCHMIDT et al. 2010, ÚJVÁRI et al. 2014). A kozmikus sugárzás értékét PRESCOTT \& HutToN (1994) alapján becsültük.

\section{Eredmények}

\section{A siklóbevágás kainozoos összletének üledékes egységei}

A feltárásban a mai feltártsági viszonyok közt három eltérô kôzetanyagú üledékes egységet lehetett elkülöníteni
(3. ábra), melyek a mezozoos rétegsorra szögdiszkordanciával települnek. A feltárás legnagyobb részét kitevő homokos kavics (A) és az ebbe települő homok (B) teszi ki. A kavicszsinóros aleurit (C) ezekre egy íves felszín mentén települ. Talajosodás nyomai nem figyelhetők meg a rétegsorban; az egyes egységek eróziós felszínek mentén érintkeznek egymással. A feltárás felső részét lejtőtörmelék alkotja, éles, szögletes kavicsokkal, helyenként nagyobb tömbökkel. Ősmaradványok nem kerültek elő egyik egységből sem.

\section{A) Homokos kavics}

A feltárás nagy részén, 20 méteres szakaszon homokos durva kavics települ a triász-jura alaphegységre, egyenetlen, helyenként eróziósan kimélyülő talpfelszínnel és átlagosan 2 méteres vastagsággal (3. és 4. ábra). Színe változó, világos, szürkés vagy barnás. Nem láthatók benne határozott réteghatárok, de lapos, lencseszerú testekben elkülöníthetők benne kissé eltérô szövetú részek: változó szemcseméretű kavics, homokos kavics, alárendelten kavicsos homok. A kavics az egész egységben szemcsevázú. A kavicsok mérete 1-2 cm-tôl a 30 cm-es átmérôig terjed, a feltárás déli részén a jellemző szemcseméret valamivel nagyobb, mint az északin. Az egyes lencsék viszonylag jól osztályozottak. A kavicsok koptatottsága változó a szögletestől a jól koptatottig, jellemzően közepes, de jelentős számban találhatók jól koptatott kavicsok is (4. ábra). A kavics mátrixa durva homok, amely világos vörös vagy szürke színú, egyes lencsékben hiányzik. A homokszemcsék anyaga kvarc és karbonát, kis mennyiségben földpát; a kötőanyag karbonát. Határozott zsindelyesség nem látható. Az összletben krioturbáció vagy más deformáció nem figyelhetô meg.

VöRÖs (2010) cikkében az 1979-ben készült fényképek a mainál jobb állapotban mutatják a siklóbevágást, így a most vizsgált kainozoos képződményeket is: az idézett mú 19.
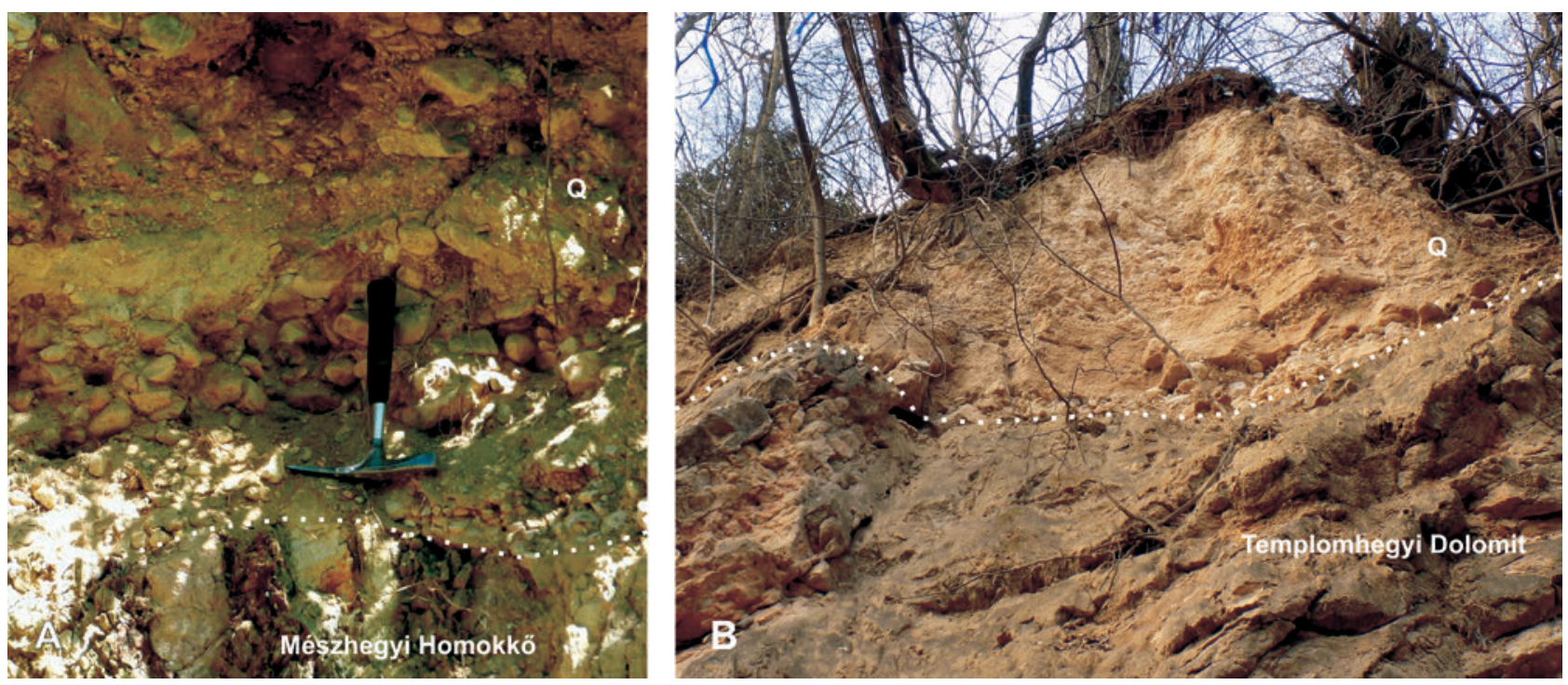

4. ábra. Homokos kavics egység. A) Mészhegyi Homokkőre települỏ homokos kavics a siklóbevágás déli részén; B) Templomhegyi Dolomitra települő, kb. $2 \mathrm{~m}$ vastag kavics a siklóbevágástól nyugatra lévő dombon

Figure 4. Sandy gravel unit. A) Coarse gravel overlying Mészhegy Sandstone in the southern part of the cable-car cut, with weak bedding; B) Approx. $2 \mathrm{~m}$ thick gravel overlying Templomhegy Dolomite on the hill west of the cable-car cut 
ábrája a feltárás déli végét, a 7. ábra a déli, magasabb, a 11. ábra pedig az északi, alacsonyabb felét.

\section{B) Kavicsos homok és aleurit}

A kavicsösszletben elkülöníthetô egy 8 méteres laterális kiterjedésú, legfeljebb $20 \mathrm{~cm}$ vastag, mindkét irányban kiékelődő betelepülés (5. ábra), amely párhuzamos a befogadó kaviccsal. Két részből, egy alsó, átlagosan $10 \mathrm{~cm}$ vastag homokból és egy felső, $5 \mathrm{~cm}$ vastag aleuritból áll (5. ábra, A), amelyek közül utóbbi hamarabb kiékelődik, mint a
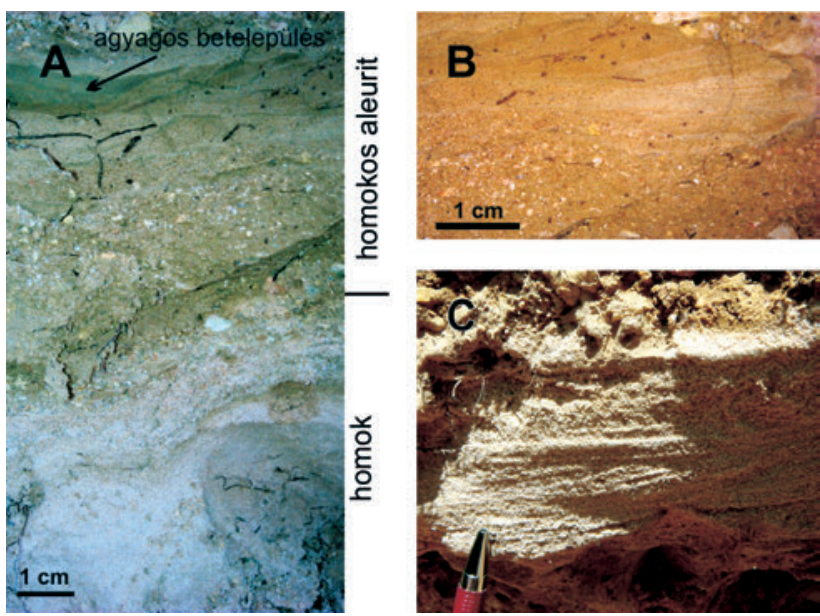

5. ábra. Kavicsos homok és aleurit. A) Az egység jellemző szelvénye; B) közelkép a felső, homokos aleuritról; $\mathrm{C}$ ) az alsó réteg keresztrétegzett homokja Figure 5. Gravelly sand and silt. A) Typical section of the unit; B) cross-bedding in the lower sand layer; $C$ ) close-up of the upper sandy silt

homok. A két réteg között a határ általában éles. A homok világos vörösesszürke, jól osztályozott, közép-durvaszemcséjú, keresztlemezes (5. ábra, C). Szemcséi közt kvarc, karbonát, muszkovit, földpát ismerhetô fel, kötőanyaga karbonátos. A mellső lemezek dőlése a kis kiterjedés miatt nehezen mérhetô, egy helyen bizonytalan 250/15 fokot mértünk. A felsô, barna, túlnyomórészt aleuritból álló réteg (valójában kisebb rétegekbôl álló köteg) szemcsemérete fölfelé csökken: alsó 2-3 cm-ében aprókavicsos durvahomok és szórtan nagyobb (max. $5 \mathrm{~cm}$-es) kavicsok figyelhetôk meg, míg felül lencsékben agyagos (5. ábra, B).

\section{C) Kavicsbetelepüléses aleurit}

A feltárás északi végén mintegy 6 méteres hosszon kőzetliszt uralta kôzettest található, amely enyhén ívelt alsó határral települ részben a triász alaphegységre, részben déli részén - a kavicsra (3. ábra). Az aleurit szürkésbarna színú, egy 5 és egy $10 \mathrm{~cm}$ vastag homokos kavicsréteg települ bele. Legnagyobb vastagsága 1,5 méter. Szerkezete lemezes, kőzetliszt- és finomhomokos kőzetlisztlemezek váltakoznak benne. Az egyes lemezek jól osztályozottak. Kötőanyaga karbonátos. A kőzetben gyakoriak a szabad szemmel is látható, $0,5 \mathrm{~mm}$ körüli átmérújő, csőszerú pórusok, melyeket meszes kitöltés vagy belsố bevonat jellemez, ezek hajszálgyökerek menti pórusokként, illetve kiválásként értelmezhetők. A kavicsbetelepülésekben a kavicsok anyaga megegyezik a helyi triász dolomitokkal és mészkövekkel. A betelepülések rosszul osztályozottak. A kisebb kavicsok 1-2 cm átmérójúek, szögletesek, míg a nagyobbak 4-5 cm méretúek és elérhetik a közepes koptatottságot is. Imbrikáció a feltárás által biztosított metszetben nem figyelhetô meg. A kavicsrétegekben előforduló homok jelentôs hasonlóságot mutat anyagában, szövetében és színében a homokos kavicsegység mátrixaként megjelenő homokkal: szemcsemérete durva, kvarc és karbonátos szemcsék is előfordulnak benne.

\section{Kavicstípusok}

A feltárásban a kavicsok uralkodóan karbonátos kőzetanyagúak. A homokos kavicsösszletet alkotó kőzettípusok fordulnak elô kisebb mennyiségben a másik két egységben is, kivéve a homokkövet, ami csak a homoklencsébőll került elő. Darakavics mérettartományban, 2-3 mm-es átmérővel koptatott kvarckavicsok is előfordulnak. Az „A” egység jellemző kőzettípusai gyakorisági sorrendben az alábbiak:

Sávos dolomit és mészkő (gyakorisága 35\%). Jellemzően világos színú, halványszürke, -vörös és/vagy -sárga sávos, néha foltos (6. ábra, 3, 4), szórványosan mangándendrites. A színes sávok általában, de nem mindig a rétegzést követik. Oldásos üregek és kisebb kőzetrések mentén kalcitkiválások figyelhetók meg benne. Alig-jól koptatott, kemény. Szövete tömör, mikrites. 6-10 cm-es átmérôvel rendelkezik átlagosan, de a 15-20 cm-t is elérheti. Makroszkópos megjelenése alapján a középső-triász Csukmai Formáció Templomhegyi Dolomit Tagozatából származik.

Pátos meszes dolomit ( 20\%). Vörös-sárga színú kôzet, fekete foltokkal (6. ábra, l). Pátos szövetú, a repedésekben kalcitkitöltésekkel. Jól koptatott, kemény, átlagos átmérője 8 $\mathrm{cm}$. Hasonló színú durvakristályos dolomitot a siklóbevágástól északra, a villányi vasútállomástól délre fekvő kőfejtôből a Templomhegyi Dolomitból említ NAGY E. \& NAGY I. (1976).

Breccsás dolomit ( 15\%). Világos árnyalatú, fehér, szürke, sárga, illetve vörös, tömör, mikrites dolomit, néha kalcitos erekkel. Breccsás szövetú, a világos, szögletes klasztok közt vöröses, szintén dolomit anyagú mátrix van (6. ábra, 2). 5-13 cm átmérójú, közepesen-jól koptatott szemcsékként fordul elő. Ilyen kôzetanyag a Templomhegyi Dolomitot jellemzi a környéken, leginkább vetőbreccsaként, például a siklóbevágástól északra és nyugatra lévő kőfejtőkben.

Kalciteres márga ( 15\%). Világos, sárga vagy barna színú üledékes kôzet (6. ábra, 5). Repedések mentén kivált rostos, pátos kalcitból, valamint kevés agyagból vagy márgából áll, sok üreggel, melyekből a márga kimosódott vagy kioldódott. Kis keménységú. Szögletes vagy alig koptatott kavicsokként fordul elő, akár egészen nagy, akár $20 \mathrm{~cm}$-es méretben. Feltehetôen a Mészhegyi Homokkő alsó részéből származik.

Durva pátos kalcit vörösagyaggal ( 5\%). A kavicsok világossárga színú, nagy (akár $3 \mathrm{~cm}$ hosszú), sugaras, vagy kisebb, hullámos vagy koncentrikus lemezekben elhelyezkedő kalcitkristályokból, valamint meszes vörösagyagból állnak (6. ábra, 8). Koptatottak, méretük átlagosan 5-6 cm, legfeljebb $11 \mathrm{~cm}$. A sugaras kalcitokra merőleges felszíne- 


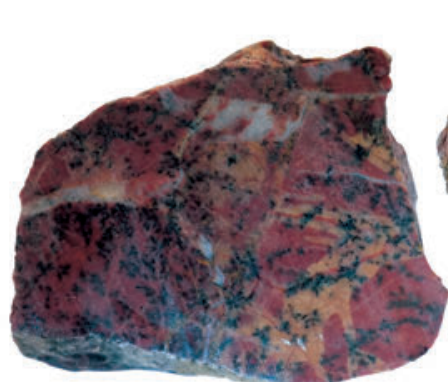

1.

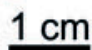

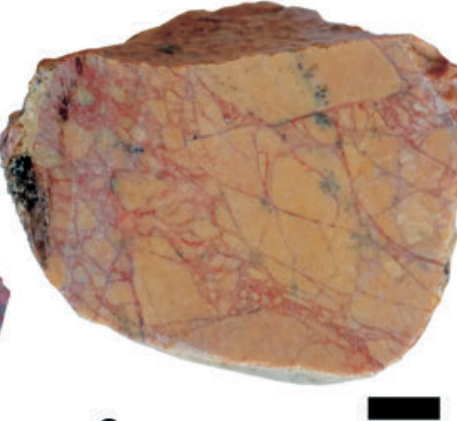

2.

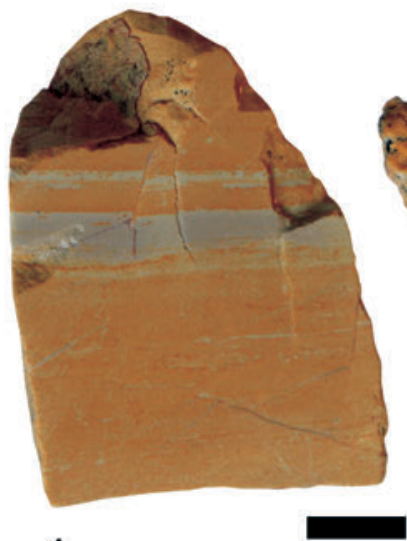

4.

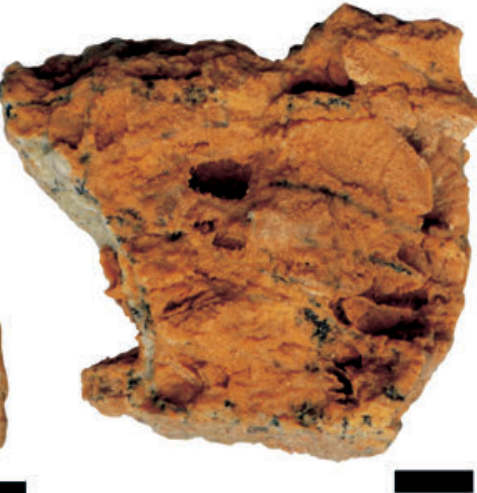

5.

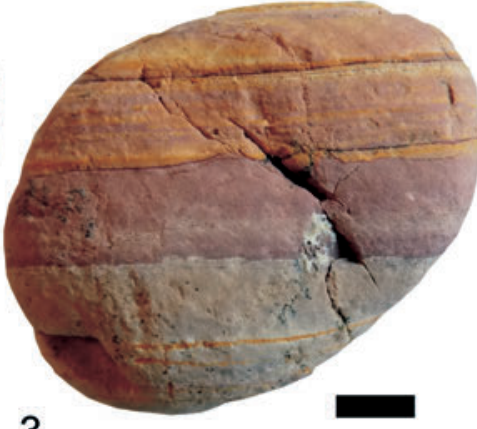

3.

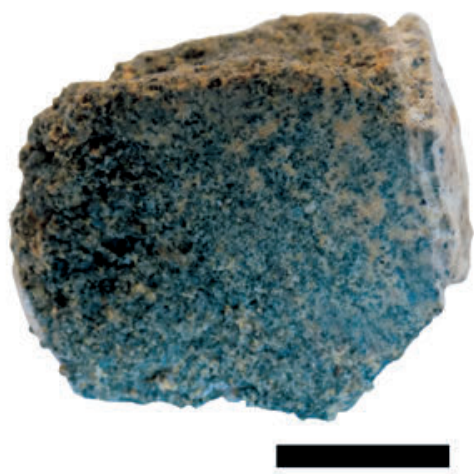

6.
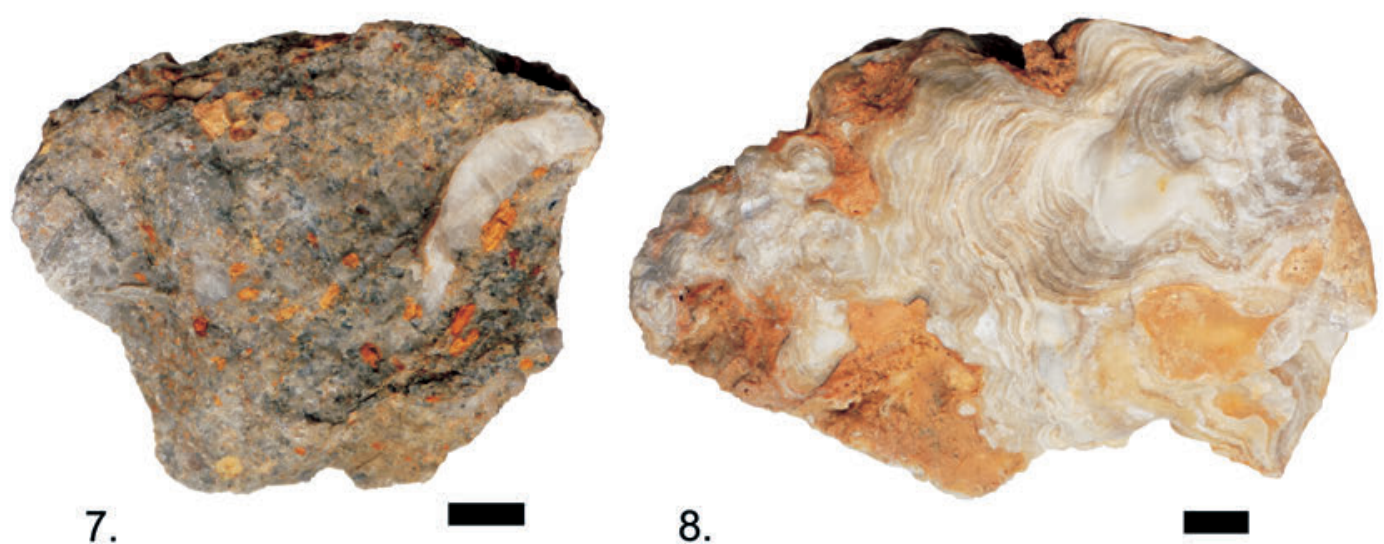

6. ábra. A feltárás jellemző kavicstípusai (kor szerinti sorrendben). 1 - pátos dolomit, 2 - breccsás dolomit, 3 - sávozott mészkő, 4 - réteges dolomit, 5 - kalciteres márga, 6 - homokkő, 7 - szürke, homokos mészkő molluszka héjtöredékkel, 8 - pátos kalcit vörösagyaggal

Figure 6. Characteristic clast lithologies. 1-sparry dolomite, 2-brecciated dolomite, 3-banded limestone, 4-banded dolomite, 5-marl with calcite veins, 6 - sandstone, 7 - grey, sandy limestone with fossils, 8 -coarse sparry calcite with red clay

ken a cseppkövekre jellemző hullámos felületek (lemezek) figyelhetők meg. Az üregeket vörös agyag tölti ki. Ilyen kőzetanyag karsztos üregek kitöltéseként fordul elố a környéken. A legközelebbi dokumentált előfordulások a siklóbevágástól északnyugatra, alacsonyabban lévő és a délre fekvő, felső, nagy kőfejtőben, valamint a Somssich-hegyen vannak, de a feltárástisztításkor a Mészhegyi Homokkőben is találtunk vörösagyaggal kitöltött függő́leges hasadékot. Az ősmaradványokat is tartalmazó közeli előfordulások kora 2 millió év (Villány-3 lelőhely) és 640 ezer év (Villány-6) között van (KoRMos 1917, PAZONYI 2009).

Homokos, héjtöredékes mészkő (szórványos). Szürke, tömör, homokos mészkő, molluszka- és brachiopoda-héjtöredékekkel, néhány mm-es rozsdavörös, kerekded agyagkavicsokkal (6. ábra, 7). Alig-közepesen koptatott, max. 15 cm-es kavicsokként fordul eló. Nagyon jellegzetes megjelenésú kőzetanyag, egyértelmúen az alsó-jura Somssichhegyi Mészkőbőll származik. 
Homokkő (szórványos). Csak a homokos betelepülésből került elő egy 20 cm-es, alig koptatott darab. Barnássárga, szürke foltos kavics (6. ábra, 6). Felszínét karbonátos kötőanyag cementálja, ezért a külseje sokkal keményebb, ellenállóbb a belsejénél, ami alig kötött. A szemcsék anyaga kvarc, karbonát és földpát. Kőzetanyaga makroszkópos megfigyelés alapján megegyezik a fekü felső-triász Mészhegyi Homokkő homokkőrétegeiével.

A kavicsok közül többször azok is pezsgéssel reagálnak sósavra, amelyek makroszkópos megjelenésük alapján egyértelmúen a Templomhegyi Dolomitból származnak. Ennek oka az lehet, hogy a felszín közelében mállott a kőzetanyag, valamint hogy a karbonátos anyagú hegységben a talajvíz erősen meszes és ez átitatta ôket. A karbonátos átitatás egyértelmúen megfigyelhetô a Mészhegyi Homokkő esetében.

\section{A homokbetelepülés ásványos összetétele}

A homokos kavicsba települő homokrétegben a vizsgált 100-200 m-es szemcseosztályban a nehézásvány-frakció aránya nem éri el az 1 súly\%-ot. A nehézásvány-társulás (7.

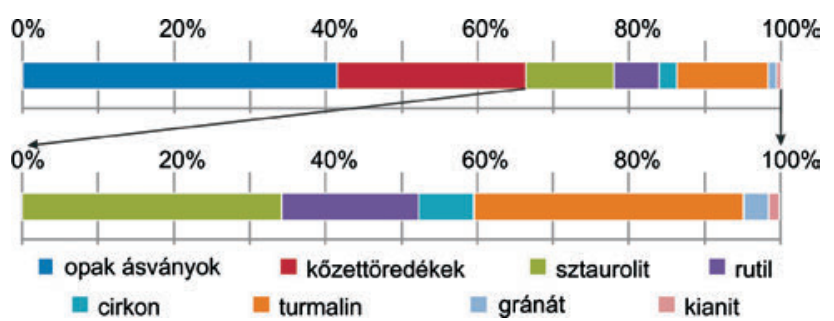

7. ábra. Az „A” egységbe települő homok nehézásvány-összetétele Figure 7. Heavy mineral composition of the sand interbed in the gravel ábra) döntően opak ásványokat (41,6 \%) és kőzettöredékeket $(24,9 \%)$ tartalmaz. Az opak ásványokat az ilmenit(?), a magnetit(?) és a hematit képviselik. Az átlátszó ásványok közül a legnagyobb gyakorisággal a turmalin (11,9\%) és a sztaurolit (11,5\%) fordul elő. A turmalin saját alakú, törött, világossárga-sötétbarna vagy színtelen-sötétbarna pleokroizmust mutat. A sztaurolitszemcsék felszíne gyakran mart, a prizmák szélein olykor fúrészfogszerú. Közel azonos arányban fordul elő a színtelen vagy szürke, saját alakú, belsô zónásságot mutató, zárványos cirkon, valamint a szürke, zömök, koptatott cirkon. A rutil vörös vagy narancssárgás vörös színú, koptatott, ritkábban jól koptatott. Kevés színtelen gránát és kianit van jelen. A szemcsék többnyire kissé koptatottak, kissé bontottak. A kiértékeléskor nem számoltuk a preparátumban előforduló színtelen muszkovitot és halványzöld, kloritosodó biotitot.

\section{Lumineszcens kormeghatározás}

A lumineszcens mérések alapján az 1. jelú, homoklencséból vett minta kvarc frakciójában (90-150 $\mu \mathrm{m})$ a lumineszcens jel a várakozásoknak megfelelően telített volt ( 8 . ábra, A). A felállított exponenciális+lineáris függvénykombináció alapján a kvarcfrakció elvi mérési határa több részminta mérési átlagát figyelembe véve $2 \times \mathrm{D}_{0}=153 \pm 16 \mathrm{~Gy}$, ami megfelel a szakirodalomban máshol közölt értékeknek (WinTLE \& MurRAY 2006). A kvarcra számított dózistel-

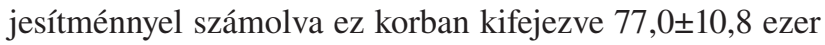
évnek felel meg (I. és II. táblázat).

A post-IR IRSL ${ }_{225}$ mérés esetében a természetes jel telítettséghez közeli intenzitást mutatott. Ez esetben exponenciális függvényt lehetett a dózis/lumineszcens válasz
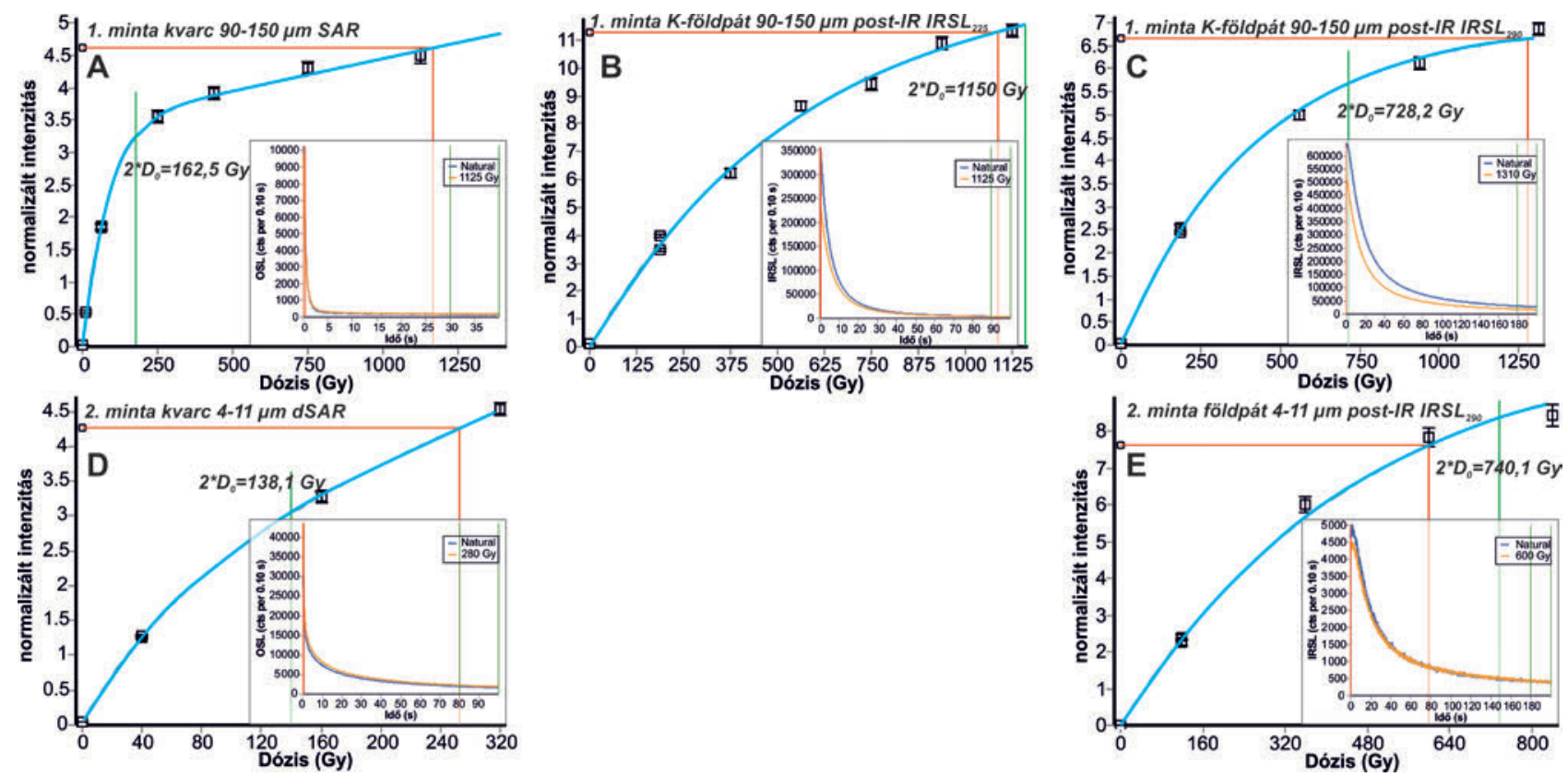

8. ábra. Egy-egy reprezentatív részminta (korong) esetében mért dózis - lumineszcens válasz összefüggés. A természetes lumineszcens intenzitást és az egyenérték dózist piros vonal, a felső határát jelző $2 \times \mathrm{D}_{0}$ értéket zöld vonal jelzi

Figure 8. Dose response curves of representative aliquots. Natural luminescence intensity and related equivalent dose is marked by red, the upper limit of measurements $\left(2 \times D_{0}\right)$ by green 
I. táblázat. A mintákra számított dózisteljesítmény-értékek

Table I. Dose rate values calculated for the samples

\begin{tabular}{|c|c|c|c|c|c|c|c|c|c|c|}
\hline Minta & $\begin{array}{c}\text { Mélység } \\
\text { (m) }\end{array}$ & $\begin{array}{c}\mathrm{U} \\
(\mathrm{ppm})\end{array}$ & $\begin{array}{c}\text { Th } \\
(\mathrm{ppm})\end{array}$ & $\begin{array}{c}\mathrm{K} \\
(\%)\end{array}$ & $\begin{array}{c}w \\
(\%)^{\prime}\end{array}$ & $\begin{array}{c}\mathrm{D}_{\text {tam }}^{*} \\
(\mathrm{~Gy} / \mathrm{ka})^{2}\end{array}$ & $\begin{array}{l}\mathrm{D}^{*}{ }_{99-150, \mathrm{~mm}} \\
(\mathrm{~Gy} / \mathrm{ka})^{3}\end{array}$ & $\begin{array}{l}\mathrm{D}_{\mathrm{K} / 90-150 \mathrm{~mm}}^{*} \\
(\mathrm{~Gy} / \mathrm{ka})^{\frac{4}{4}}\end{array}$ & $\begin{array}{l}D^{*} \\
(\mathrm{~Gy} / \mathrm{ka})^{5}\end{array}$ & $\begin{array}{l}\mathrm{D}^{*}{ }_{\mathrm{kf} 4-11 \mathrm{ma}} \\
(\mathrm{Gy} / \mathrm{ka})^{6}\end{array}$ \\
\hline $\begin{array}{c}1 \\
\text { (homok) }\end{array}$ & \multirow{2}{*}{4,2} & $2,15 \pm 0,13$ & $8,14 \pm 0,55$ & $1,44 \pm 0,07$ & \multirow{2}{*}{$10 \pm 5$} & \multirow{2}{*}{$0,11 \pm 0,01$} & \multirow{2}{*}{$1,99 \pm 0,18$} & \multirow{2}{*}{$2,46 \pm 0,31$} & \multirow{2}{*}{ - } & - \\
\hline $\begin{array}{c}1 \\
\text { (kavics) }\end{array}$ & & $1,72 \pm 0,10$ & $3,16 \pm 0,27$ & $0,55 \pm 0,03$ & & & & & & - \\
\hline 2 & 4,4 & $2,65 \pm 0,15$ & $9,67 \pm 0,61$ & $1,58 \pm 0,08$ & $10 \pm 5$ & $0,11 \pm 0,01$ & - & - & $3,43 \pm 0,31$ & $3,78 \pm 0,32$ \\
\hline
\end{tabular}

${ }^{1}$ a minták becsült nedvességtartalma,

${ }^{2}$ a kozmikus sugárzásból adódó dózisteljesítmény,

${ }^{3}$ a durva szemcsés $(90-150 \mu \mathrm{m})$ kvarc frakcióra számolt dózisteljesítmény,

${ }^{4}$ a durva szemcsés $(90-50 \mu \mathrm{m})$ K-földpát frakcióra számolt dózisteljesítmény,

${ }^{5}$ a finom szemcsés (4-11 $\left.\mu \mathrm{m}\right)$ kvarc frakcióra számolt dózisteljesítmény,

${ }^{6}$ a finom szemcsés (4-11 $\left.\mu \mathrm{m}\right)$ földpát frakcióra számolt dózisteljesítmény.

összefüggéshez a legjobban illeszteni (8. ábra, B). Az erre a mintára számított egyenérték dózis 1019 28 Gy-nek adódott. A számított átlagos mérési határ K-földpát esetben jóval magasabb, azaz $986 \pm 98$ Gy volt (II. táblázat). Elvileg tehát a kapott egyenértékdózis a felső méréshatár hibahatárán belül van, ez azonban nem jelenti azt, hogy a

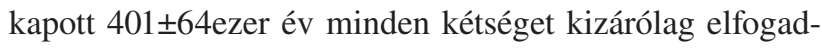
ható. A telítettséget támasztja alá, hogy a stabilabban teljesítő post-IR IRSL ${ }_{290}$ mérés esetében gyakorlatilag nem lehetett egyenérték dózist meghatározni, ugyanis a természetes intenzitások jóval a maximálisan mérhető intenzitások felett voltak $\left(8\right.$ ábra, C). A mérési határ $\left(2 \times \mathrm{D}_{0}=\right.$ $879 \pm 21$ Gy) egyébként közel esett az előzőekben mért értékhez (II. táblázat). A 2. jelú, löszből vett minta finomszemcsés kvarc frakciója a double-SAR mérések kapcsán ugyancsak telítettséget mutatott (8. ábra, C). Ez esetben szintén exponenciális+lineáris függvénnyel lehetett a legjobban leírni a lumineszcens intenzitások alakulását. Az ezekből számolt telítôdési dózis $2 \times \mathrm{D}_{0}=134 \pm 5$ Gy volt, ami

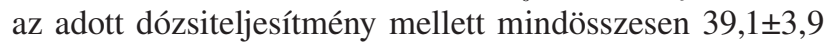
ezer évnek felel meg (II. táblázat).

A polimineralikus mintán elvégzett post-IR IRSL $_{290}$ mérés kapcsán kapott elvi mérési határ $968 \pm 94$ Gy volt, ami jól illeszkedik az 1. minta esetében tapasztalt telítettségi

II. táblázat. A mért egyenérték dózis értékek (De) és felső mérési határok $\left(2 \times \mathrm{D}_{0}\right)$ több mérés átlaga alapján, valamint az ebből számított koradatok

Table II. Measured equivalent doses (De) and upper measurement limits $\left(2 \times D_{0}\right)$ based on the mean of several measurements, and the calculated ages

\begin{tabular}{|c|c|c|c|c|c|c|}
\hline Minta & Protokoll & $\begin{array}{c}\mathrm{n} \\
(\mathrm{db})\end{array}$ & $\begin{array}{c}\mathrm{D}_{e} \\
(\mathrm{Gyy})\end{array}$ & $\begin{array}{c}2^{*} \mathrm{D}_{0} \\
(\mathrm{Gyy})\end{array}$ & $\begin{array}{c}\text { Kor } \\
\text { (ezer év) }\end{array}$ & $\begin{array}{c}\text { Minimum } \\
\text { kor } \\
\text { (ezer év) }\end{array}$ \\
\hline 1 & SAR & 8 & $827 \pm 70$ & $154 \pm 16$ & - & $77 \pm 11$ \\
\hline 1 & postIR IRSL $_{25}$ & 9 & $1019 \pm 28$ & $986 \pm 98$ & $415 \pm 54$ & $401 \pm 64$ \\
\hline 1 & postIR IRSL $_{20}$ & 3 & - & $879 \pm 21$ & - & $357 \pm 46$ \\
\hline 2 & double-SAR & 12 & $237 \pm 2$ & $134 \pm 5$ & - & $39 \pm 4$ \\
\hline 2 & postIR IRSL $_{200}$ & 6 & $701 \pm 26$ & $968 \pm 94$ & $185 \pm 17$ & - \\
\hline
\end{tabular}

értékekhez. Mindazonáltal, ezúttal a mért egyenérték dózisok egy kivételével a határérték alattiak voltak (8. ábra, E), azaz ez esetben tényleges kor számítása is lehetôvé vált, ennek értéke $185 \pm 17$ ezer év.

\section{A kavicsos üledék elterjedése}

A siklóbevágásban az alaphegységre települő durva kavics megléte régóta ismert. SZABÓ (1957) kéziratos szelvényén jól látszik, hogy a kavics dél felé a Somssichhegyi Mészkốig terjed, és utóbbival együtt lösz és lejtôtörmelék fedi ôket. Rajzán jelöli, hogy a kavicsanyag délen, a jura mészkô mellett a legdurvább, ahogy ma is megfigyelhetô. Ezt a szelvényt VADÁsz (1960; 66. ábra) kiegészítve, ám a fedôhegységet tekintve kissé pontatlanul veszi át. Hasonlóképpen ábrázolja a fedőhegységet VöRös (1990), míg RÁLISCHNÉ FELGENHAUER (1985) szelvénye nem mutatja be.

A kavicsos összlet nemcsak a siklóbevágásban, hanem az annak nyugati oldalán lévő, mészkôből és dolomitból álló kiemelkedés tetején is megtalálható. A kiemelkedés déli falában a Somssichhegyi Mészkő fölött, átlagosan $1 \mathrm{~m}$ (maximálisan $2 \mathrm{~m}$ ) vastagságban és $40 \mathrm{~m}$ hosszban figyelhetô meg. A kavics itt is viszonylag jól osztályozott, durva (8-10 cm jellemzó átmérójú), változó koptatottságú, és uralkodóan karbonátos kôzetekből áll. A környék bejárása során ezen az előforduláson, a Templom-hegy nyugati oldalán kívül nem találtunk hasonló kavicsfeltárást.

\section{Az eredmények értelmezése}

\section{Az. üledék származási helye}

A homokos kavics összlet kavicsanyagának makroszkópos vizsgálata alapján elmondható, hogy a kavics helyi forrásból származik. A forráskőzetként azonosított képződmények az alaphegységet alkotó középsô-triász-alsó-jura formációk, a Templomhegyi Dolomit, a Mészhegyi Homokkő és a Somssichhegyi Mészkő, valamint a pleisztocén korú vörösagyag-kalcit üregkitöltései. Ezek a képződmé- 
nyek mind megtalálhatók a közvetlen közelben, a Templomhegy és az attól kb. 200 méterrel nyugatra fekvő Somssichhegy területén, a hegyek északi oldalán (2. ábra). Távolabbról, például a Villányi-hegység délebbi részéról vagy a Mecsekből származtatható kőzetanyag nem került elő. A kavicsok vegyes, részben gyenge koptatottsága sem utal túl hosszú szállításra.

A kavicsbetelepüléses aleurit (C egység) kavicsainak kőzetanyaga szintén a helyi alaphegységből származik. Mivel itt a koptatottság sokszor kifejezetten gyenge, a kavicsoknak igen rövid szállítás során kellett mai helyükre kerülniük. A jobban koptatott törmelékanyag részben a homokos kavicsegységből történó áthalmozásból származhat.

A kavicstestbe települó homok nehézásványos összetétele alapján változatos összetételú, döntően metamorf ásványtörmelékkel jellemezhetố származási terület, illetve forráskôzetek valószínúsíthetők. A homoklencse ásványos összetételét a helyben megtalálható felső-triász Mészhegyi Formációval és alsó-jura Somssichhegyi Formációval és a területtól északra meglévő pannóniai homokokéval vetettuik össze.

A Villányi-hegység közvetlen északi előterében előforduló pannóniai üledékekről nem rendelkezünk mikromineralógiai ismeretekkel, az összehasonlítás alapját a Mecsek és a Villányi-hegység közötti területet jellemző (Pécs-)nagyárpádi és (Pécs-)üszögpusztai homokból született adatok (HeRmann 1957, Kleb 1968) képezik. E két előfordulást döntően magnetit, cirkon, gránát, klorit, kevesebb apatit, kianit, epidot, turmalin, zöld amfibol, ilmenit jellemzi a 100-120 $\mu \mathrm{m}$-es szemcsefrakcióban, melyek többsége megtalálható a homoklencse nehézásvány-társulásában is. Az ásványtípusok további diagnosztikus tulajdonságainak hiányában (például alak, szín, belsố szerkezet) ezek az adatok korlátozottan használhatók fel.

A homoklencse nehézásvány-társulása nagyfokú hasonlóságot mutat a karni Mészhegyi Homokkőből és a pliensbachi Somssichhegyi Mészkő törmelékes alsó szakaszából megismert ásványtársuláshoz (PoZSGAI et al. in press), mind az ásványok minőségét, színét, alaki tulajdonságait és mállási bélyegeit tekintve. A jó azonosíthatóság alapján arra következtetünk, hogy a lepusztulás nagy arányban érintette a közvetlen környezet mezozoos forráskőzeteit. Tekintettel a Somssichhegyi Formáció homokkőrétegeinek kötöttségére, a származás a Mészhegyi Formáció laza, gyengén cementált homokköveiből valószínúsíthető. Ezt támasztja alá a homokbetelepülésben talált, a Mészhegyi Homokkőból származó homokkô anyagú kavics is.

\section{Lehetséges üledékképzóf folyamatok}

A homokos kavicsegység üledékszerkezetei nem látványosak és nem túl jellegzetesek; a korábbi kutatások mezozoikumra koncentrálása mellett ez is oka lehet annak, hogy ezzel a kőzettesttel eddig kevéssé foglalkoztak. A fentiek miatt az üledéket lerakó folyamatok meghatározása sem egyszerú.

A lehetséges üledékképző folyamatok közt a kőbányák szomszédságában akár az antropogén hatás is felmerülhet. A bányameddóként való értelmezést azonban kizárják a többé-kevésbé lekerekített kavicsok, az „A” egységre települő aleurit in situ kialakult pleisztocén szerkezete (pl. gyökér menti kalcithártyák), valamint az OSL kormeghatározás eredménye.

Feltételezhetố lenne az is, hogy a kavicsos összlet lejtőtörmelék. Ebben az esetben azonban a kavicsanyag jelentős része nem lenne koptatott. A feltárásban a gravitációs úton szállítódó törmeléknél várt lejtőirányú gradációt sem figyelhetjük meg: leguruló kavicsok esetén a legnagyobb darabok szállítódnak legmesszebb, a feltárásnak viszont a legfelső részén látható a legdurvább törmelékanyag. Szintén a lejtőtörmelék ellen szól, hogy a feltárástól a hegy csúcsáig a szintkülönbség nincs több 20 méternél (2. ábra). Emiatt az is valószínútlen, hogy korábban koptatott kavicsok halmozódtak át lejtômozgással, hiszen a feltárásnál magasabban fekvő lehetséges forrásterület kiterjedése nagyon kicsi.

A koptatott kavicsok hosszabb idejú szállításra utalnak, ez alapján abráziós vagy folyóvízi eredet jöhet szóba. A helyi anyagok dominanciája jellemző lenne az abráziós környezetre. Jelenlegi ismereteink szerint a területen abrázióra képes nagyobb állóvíz utoljára a késô-miocénben volt jelen (a Pannon-tó). A késô-miocén kort viszont nem teszi valószínúvé az üregkitöltő, vörösagyaggal társuló kalcitok jelenléte. Magukban a kavicsokban nem fordult elő ősmaradvány, ezért elméletileg nem zárható ki, hogy kvarternél idősebbek. Kőzetanyaguk ugyanakkor megegyezik a közvetlen közelben található, gerincesmaradványok alapján pleisztocén korú (PAZONYI 2009) üregkitöltések anyagával. A kavicsösszlet minden kôzettípusának forráskőzete előfordul a közvetlen közelben, ezért a kalcit és vörösagyag anyagú kavicsokat sem indokolt messzebbról származtatni, így analógia alapján pleisztocén korúnak tekintjük ôket. A lumineszcens mérés eredménye is pleisztocén kort mutatott. Emellett a kavicsanyag vegyes, gyengétől jóig terjedő koptatottsága inkább a folyóvízi üledékekre jellemző, mint abráziós kavicsra. A homoklencse keresztlemezessége áramló vízbő́l való ülepedésre utal. A szemcseméret feltárás menti változása folyóvízi környezetre jellemző lehet: a feltárás északi részén, a kiugró, kemény alaphegységi szirt (Somssichhegyi Mészkô) tövében található a legdurvább kavics, ahol a víz erősen áramlik és közvetlenül alámossa a sziklát. A nem kifejezett rétegzés és általában az üledékszerkezetek hiánya arra utal, hogy a kavics viszonylag sekély vízfolyásban rakódott le. A szórványosan megjelenő kevésbé ellenálló, ugyanakkor szögletes vagy alig koptatott kavicsként megjelenő kôzettípusok (pl. kalciteres márga, Mészhegyi Homokkő) nem eshettek át jelentôs szállításon, ezek lejtómozgással kerülhettek a felhalmozódás helyére és keveredhettek kis mennyiségben az üledékbe. Az üledékképződési környezet így folyóvízre határolható le, azaz a kavicstest teraszként értelmezhető. Ez a megállapítás azért jelentős, mert eddig nem volt ismert folyóvízi összlet a Villányi-hegység területén. Hasonló jellegú, szintén kis távolságból származtatott kavicsösszleteket a Báni-hegységből írtak le (BANAK 2012, PIKIJA et al. 1995).

A folyóvízi rendszerekhez kapcsolódva felmerül a hordalékkúpként való értelmezés lehetősége is. Ennek 
leginkább a morfológiai viszonyok mondanak ellent. Nincs a területen olyan vízgyújtố, aminek az anyaga itt fel tudott volna halmozódni. A vizsgált feltárások egy keskeny, változó magasságú gerinc mellett helyezkednek el, a gerincnél alig alacsonyabban (1. és 2. ábra). Korábbi kutatások a pliocén-kvarter ôsmaradvány-lelőhelyek alapján azt állapították meg, hogy a Villányi-hegység kb. 3 millió éve kiemelkedett fedôje alól, és morfológiája azóta nem változott sokat (SEBE et al. 2014), azaz a vizsgált feltárások geomorfológiai környezete a maihoz hasonló lehetett a középső- és késő-pleisztocénben is. Emellett a kavicsos összlet kőzetanyagából hiányoznak a középsô- és felső-jura formációk kőzettípusai, azoké a formációké, amelyek a kavicstestnél akár csak kicsivel is magasabban, tőle délre helyezkednek el és forrásként (lepusztulási területként) szolgálhattak volna. A hordalékkúpokon gyakori törmelékfolyásnak a legalább közepes osztályozottság, a durvahomoknál finomabb frakciók hiánya mond ellent.

A „C” egység homokos aleuritjában löszre jellemző bélyegek figyelhetôk meg: a mikropórusok, illetve azok kalcitos bevonata a lágyszárú növényzet hajszálgyökerei mentén képződik. Az aleurittest alakja lapos, enyhe lejtőjú völgy kitöltésére utal. A lemezes szerkezet és a kavicszsinórok időszakonkénti felületi lemosást mutatnak. Az aleuritos összlet így „,lejtőlöszként” (lejtőn lerakódott löszként) értelmezhetô, ahol az anyag részben hullóporként, részben lejtőlemosással érkezett, de az egész összlet helyben diagenizálódott, elsôsorban a gyökerek által kiválasztott karbonát hatására.

\section{Ósföldrajzi viszonyok}

A homokos kavicsot lerakó folyó nyomozásával információkat nyerhetünk a lerakódás idején uralkodó ősföldrajzi viszonyokról. A terület mai vízhálózatát tekintve csak néhány vízfolyás jöhet szóba mint a teraszkavics szállítója.

A Dráva eddigi ismereteink szerint soha nem járt a Villányi-hegység északi oldalán. Amellett, hogy egy ekkora folyónak morfológiában is megjelenő nyomokat és nagy mennyiségú üledéket kéne hátrahagynia, a Dráva jelenlétét kizárja a távoli forrásból származó kôzetanyag és a nagy mennyiségú csillám hiánya a feltárásban; a Dráva-üledékekre mindkettő jellemzô.

A templom-hegyi kavicsot lerakó vízfolyás helyi anyagokat dolgozott fel, ezért távolabbi folyásának lefutásáról nem kapunk információt. Mivel azonban messzi forrásból származó kavicsot nem tartalmaz, azt tudjuk, hogy vízhozama és ezzel vízgyújtố területe nem lehetett túl nagy. A vizsgált feltárásban azonosított kőzettípusok megtalálhatók mind a közvetlen, igen szúk környezetben, mind a Villányi-hegység északi oldalán több helyen. A kavicsot így egy északról lefutó, de egy, a hegység északi peremén nyugat felól érkező folyó is lerakhatta. Az, hogy a kavicstest elterjedése a Templom-hegyre korlátozódik, a nyugatról érkező vízfolyás ellen szólhat, ám figyelembe kell venni azt is, hogy a meredek domborzaton kicsi egy folyóvízi kavics lerakódásának és főleg megốrződésének az esélye, ma már nem feltétlenül találjuk meg az üledékeket a folyó teljes hossza mentén.

A Templom-hegy közvetlen környezetében két vízfolyás található, amelyek szorosan a hegység előterében húzódó völgyekben futnak: a Villányi-pogányi-vízfolyás és a Karasica (9. ábra).

A Karasica a terület nagyobb vízfolyása. Vízgyújtője felnyúlik a Kelet-Mecsekig, innen a folyó délnek tart, majd a Villányi-hegység legdélebbi részénél, a Beremendi-rögnél fordul keletnek és a Báni-hegység északi előterében fut a Duna felé. Mintegy 1,5 km széles, határozott peremekkel rendelkezô völgyébe nyugatról belenyúlik a Templom-hegy (2. és 9. ábra), azaz a folyó a széles völgy kialakításakor egyenesen nekifuthatott a Templom-hegy alaphegységi rögének. Maga a siklóbevágás és a tôle nyugat felé húzódó kavics-előfordulás ugyanakkor a Karasica mai völgyétől még nyugatabbra található (2. és 9. ábra), azaz kérdéses, hogy a Karasica elérhette-e ezt a helyet. A másik szóba jöhetô vízfolyás a Villányi-pogányi-vízfolyás, amely nyugatról érkezik a Villányi-hegység északi lábát követve és a Templomhegy után torkollik a Karasicába. Az első katonai felmérés térképén (http://mapire.eu/hu; TIMÁR et al. 2011) jól látszik, hogy a vasútépítés elôtt közvetlenül a Templom-hegy alaphegységi kőzetei mellett folyt (9. ábra, B). Felté-

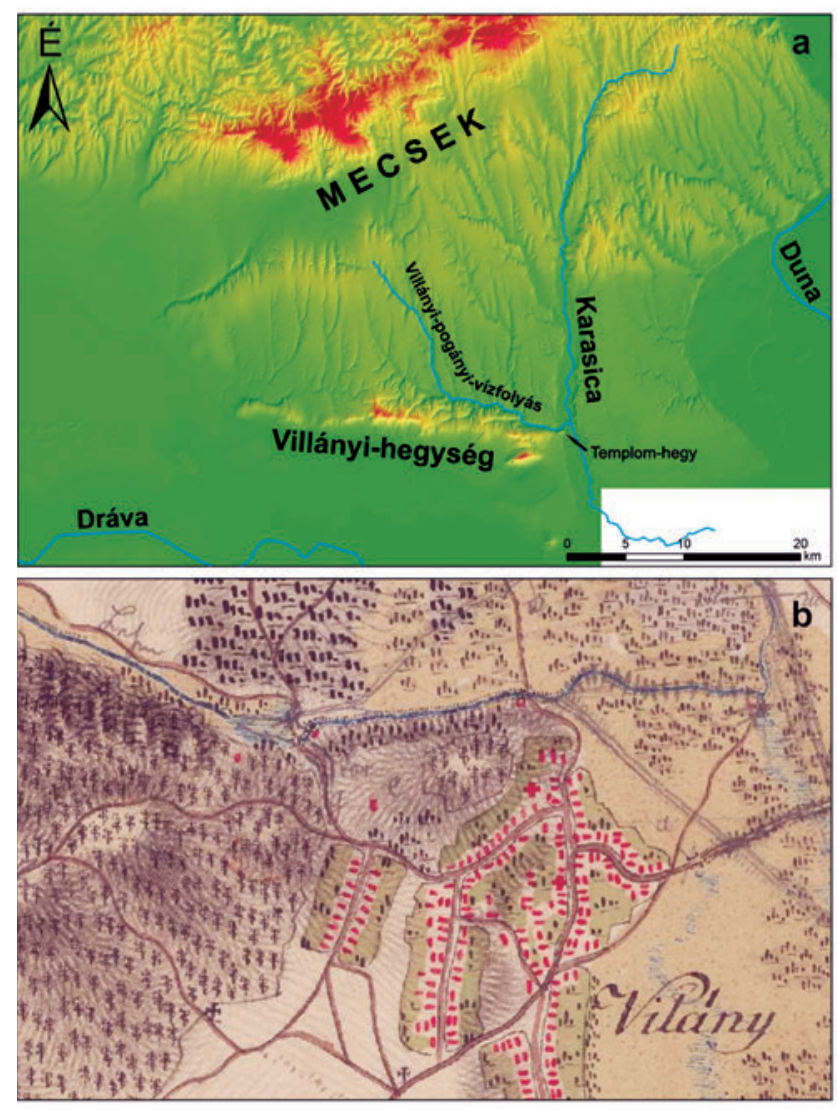

9. ábra. A) Főbb vízfolyások a Mecsektől délre eső területen; B) a Villány-pogányi-vízfolyás az I. katonai felmérés térképén (1763-1787) (http://mapire.eu/hu; TIMÁr et al. 2011)

Figure 9. A) Main watercourses south of Mecsek Mountains; B) the Villány-Pogány Stream in the map of the 1st Military Survey (1763-1787) (http://mapire.eu/hu; TIMÁR et al. 2011) 
telezhetjük, hogy ez a negyedidőszak korábbi szakaszára is igaz lehetett, azaz valószínúleg ez a vízfolyás lehetett a kavicsterasz kialakítója. A Templom-hegytől nyugatra fekvő Somssich-hegy csúcsáról nyíló, megközelítőleg 900 ezer éves Somssich-hegy-2 lelőhelyen viszonylag sok vízhez kötött csiga és gerinces (kétéltúek, hüllők, kisemlősök) maradványait találták meg (KROLOPP 2000, PAZONYI et al. 2013, SzENTESi 2016), ez arra utal, hogy a negyedidőszakban már régóta létezhet nyugatról érkező, a hegység északi lábánál végigfutó vízfolyás. Ennek nem feltétlenül kellett egy tengerszint feletti magasságban lennie a lelőhellyel, ahogy egyes munkák feltételezték (KROLOPP 2000); a kétéltúek például több száz méterre eltávolodhatnak éves vándorlásukkor a szaporodási helyül szolgáló víztesttől (pl. KovAR et al. 2009), és ez az eltávolodás magasságkülönbségben is jelentkezik.

Akár a Villány-pogányi-vízfolyás, akár a Karasica rakta le a Templom-hegy alaphegységi képződményeire a kavicsot, feltételezhetjük, hogy a vízhálózat fó vonásaiban hasonló lehetett a maihoz, nem túl nagy vízgyújtőjü, északias irányból érkező vizekkel.

\section{Tektonikai következtetések}

A mai völgytalphoz képest magasabb helyzetben lévő kvarter folyóvízi üledék a hegység fiatal emelkedéséról szolgáltat információt. A korábbi kutatások teljes egyetértésben vannak a tekintetben, hogy a Villányi-hegység jelenleg emelkedő mozgást végez. Mikrotektonikai mérések és szeizmikus szelvények vizsgálata alapján CsONTOS et al. (2002) szerint a Villányi-hegység a késő-miocén óta ÉNyDK-i kompresszió hatására egy jobbos eltolódási zónában emelkedik. Ez összhangban van BADA et al. (2007) azon eredményeivel, hogy a területen GPS-adatok és feszültségmérések alapján jelenleg eltolódásos-transzpressziós feszültségtér uralkodik. PETRIK (2009) a Villányi-hegység mezozoos képződményeinek mikrotektonikai vizsgálata során pliocén-kvarter ÉK-DNy-i transzpressziós feszültségteret azonosított. A Villányi-hegység HoRvátH \&
Cloetingh (1996) szerint is emelkedik. Az idézett következtetéseket jórészt mezozoos képződményeken végzett mérések és felső-miocénnél nem fiatalabb üledékeket leképező szeizmikus szelvények alapján vonták le. A vizsgált kvarter üledék segítségével ezt a képet pontosíthatjuk.

Az egykori völgytalpat jelző folyóvízi kavicstestnek a mai vízfolyáshoz viszonyított magasságából és korából megbecsülhető az adott időszakra a terület átlagos emelkedési üteme. A kavicstest homoklencséje a lumineszcens kormeghatározás szerint több mint 400 ezer éves. A feltárás a mai völgytalpnál körülbelül 20 méterrel magasabban található (10. ábra). Ebből kiszámítható, hogy az átlagos emelkedési ütem a negyedidőszak fiatalabb részében legfeljebb $\sim 0,05 \mathrm{~mm} / \mathrm{év}$ lehetett. Amennyiben a teraszkavics jelentősen idősebb 400 ezer évnél, ez a ráta akár jóval alacsonyabb is lehet. Ezek a számok a hegység viszonylag lassú kvarter emelkedésére mutatnak, hasonlóan a hosszabb távra, az utolsó 3 millió évre óslénytani alapon korolt lelőhelyek tengerszint feletti magassága alapján számolt, 0,016 mm/éves átlagos emelkedési ütemhez (SEBE et al. 2014).

\section{Következtetések}

A vizsgált durvakavicsos üledék nem értelmezhető antropogén felhalmozódásként, lejtőtörmelékként és tavi vagy tengeri abráziós kavicsként sem. A kőzetanyag alapján a kavicsok a közvetlen közelből származnak, a forráskőzetek nagy része azonosítható a Villányi-hegység északi részén található, főleg alaphegységi, kis részben fiatalabb kőzettípusokkal (Templomhegyi Dolomit, Mészhegyi Homokkő, Somssichhegyi Mészkő Formáció, üregkitöltő vörösagyag és kalcit). A rövid szállítási távolságot támasztja alá a kavicsok vegyes, gyenge-jó koptatottsága és a kavicsba települő homok nehézásvány-összetétele is; utóbbi leginkább a közvetlen fekü felső-triász Mészhegyi Formációval és alsó-jura Somssichhegyi Formációval rokonítható. Az összlet, a környéken pleisztocén korú üregkitöltő kalcit

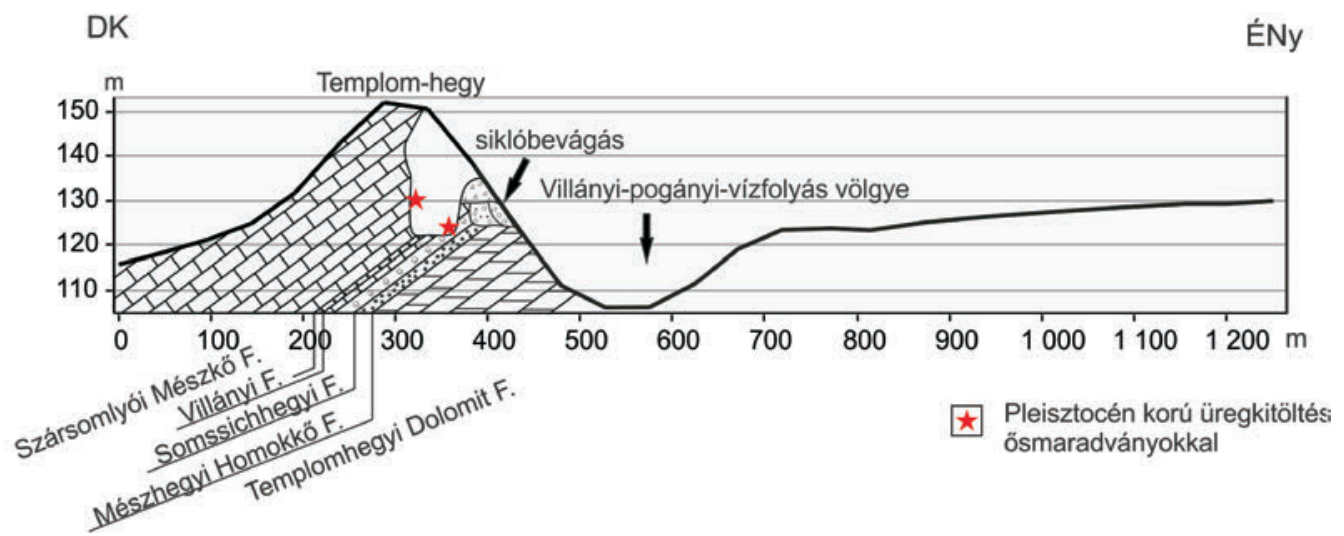

10. ábra. A Templom-hegy és a Villányi-pogányi-vízfolyás völgyének domborzati keresztmetszete. Az alaphegység felépítése Vörös (2010) mủvéből átvéve. A szelvény lefutását 1. a 2. ábrán

Figure 10. Cross-section of Templom Hill and valley of Villány-Pogány stream. Structure of basement from VöRös (2010). For the location of the cross-section see Figure 2 
és vörösagyag anyagú kavicsok alapján, pleisztocénnél nem idősebb; a homok lumineszcens módszerrel mért kora legalább 400 ezer év. A fentiek alapján a kavicsösszletet egy, a késő-pleisztocénnél korábban már létező vízfolyás üledékeként, folyóvízi teraszként értelmezhetjük. Ez a folyóvíz a mai Villány-pogányi-vízfolyás őse lehetett, amely a hegység északi előterében, végig szorosan annak lábánál haladva érinti a meghatározott forráskőzeteket.

A Villányi-hegység vizsgált területén a pleisztocén fejlődéstörténet a rendelkezésre álló információk alapján a következő lehetett: A Villányi-pogányi-vízfolyás a Templomhegy északi oldalán, alaphegységi kőzeteken futott, azokat részben erodálta, részben pedig lerakta rájuk hordalékát, mielőtt a Karasica széles völgyébe futott volna. Ez a középsőpleisztocénben történhetett. A hegység lassú emelkedésével a vízfolyás bevágódott, a kavicstest szárazra került és erodálódott, kis, lapos völgy (vízmosás vagy inkább aszóvölgy, delle) vágódott bele. Ez később, a riss eljegesedés (azon belül a MIS 6 oxigénizotóp-stádium) során viszonylag rövid idő alatt kitöltődött lösszel és felületi lemosással szállítódó homok-kavics méretú törmelékkel. A teljes összletet átjáró, a hajszálgyökerek helyét jelző kalcithártyás mikropórusok alapján a hullóporos anyag diagenezise (a lösz képződése) lépést tudott tartani az üledékfelhalmozódással. Az anyagszállítás a mai völgy (a Villány-pogányi-vízfolyás völgye) felé történt. A terület emelkedési üteme a negyedidőszak második felében legfeljebb 0,05 mm/év, de akár ennél jóval kisebb is lehetett.

\section{Köszönetnyilvánítás}

A munkát támogatta az OTKA (PD 104937), valamint a TÁMOP 4.2.4.A/2-11-1-2012-0001 Nemzeti Kiválóság Program címú kiemelt projekt, az Európai Unió támogatásával, az Európai Szociális Alap társfinanszírozásával. A feltárás letisztítását a Pécsi Tudományegyetem Földtudományok Doktori Iskolája finanszírozta. Hálásak vagyunk VöRös Attilának, aki korábbi fényképeit, megfigyeléseit és írásos anyagait rendelkezésünkre bocsájtotta. Köszönjük a lektorok, THAMónÉ Bozsó Edit és BRADÁK Balázs gondolatébresztő kritikáit.

\section{Irodalom - References}

AdAmiEC, G. \& AitKen, M. J. 1998: Dose-rate conversion factors: update. - Ancient TL 16/2, 37-50.

Bada, G., Grenerczy, Gy., Tóth, L., Horváth, F., Stein, S., Cloetingh, S., Windhoffer, G., Fodor, L., Pinter, N. \& Fejes, I. 2007: Motion of Adria and ongoing inversion of the Pannonian Basin: Seismicity, GPS velocities, and stress transfer. — In: STEIN, S. \& MazzotTi, S. (eds): Continental Intraplate Earthquakes: Science, Hazard, and Policy Issues. Geological Society of America Special Paper 425, 243-262. http://dx.doi.org/10.1130/2007.2425(16)

BANAK, A. 2012: Rekonstrukcija klimatskih promjena u kasnom pleistocenu na temelju sedimentologije prapora te paleontološke $i$ izotopne analize malakofaune (Baranja, istočna Hrvatska). (Reconstruction of Late Pleistocene climate change based on loess sedimentology, malacofaunal palaeontology and isotope analysis (Baranja, eastern Croatia).) — PhD Thesis, University of Zagreb, $155 \mathrm{p}$.

Csontos, L., MÁrton, E., Wórum, G. \& Benkovics, L. 2002: Geodynamics of SW-Pannonian inselbergs (Mecsek and Villany Mts, SW Hungary): Inferences from a complex structural analysis. — EGU Stephan Mueller Special Publication Series 3, $227-245$. http://dx.doi.org/10.5194/smsps-3-227-2002

CHIKÁN G., MARSI I. \& BUdAi T. 2005: Magyarország földtani térképe, Siklós (L-34-73) 1:100 000 térképlap. — Magyar Állami Földtani Intézet, Budapest.

HERMANN M. 1957: A Mecsek hegység és pereme pannóniai homokjainak mikromineralógiai vizsgálata. — Annales Historico-Naturales Musei Nationalis Hungarici 8, 23-29.

Horváth, F. \& Cloething, S. 1996: Stress-induced late-stage subsidence anomalies in the Pannonian basin. — Tectonophysics 266, 287300. http://dx.doi.org/10.1016/S0040-1951(96)00194-1

HunTLEy, D. J. \& BARIL, M. R. 1997: The K content of the K-feldspars being measured in optical dating or in thermoluminescence dating. -Ancient TL 15/1, 11-13.

KLEB B. 1968: A Mecsek-hegység déli előtere pannóniai képződményeinek üledékföldtani vizsgálata. — Földtani Közlöny 98/3-4, 335-359.

Kormos T. 1917: A Villányi hegység preglaciális képződményei és faunájuk. — A Magyar Királyi Földtani Intézet Évi Jelentése 1916ról, 99-415.

Kovar, R., Brabec, M., Vita, R. \& BoceK, R. 2009: Spring migration distances of some Central European amphibian species. Amphibia-Reptilia 30, 367-378. http://dx.doi.org/10.1163/156853809788795236

Krolopp E. 2000: Alsó-pleisztocén Mollusca-fauna a Villányi-hegységbőll. — Malakológiai Tájékoztató 18, 51-58.

Lóczy L. ifj. 1912: A Villányi és Báni hegység geológiai viszonyai. — Földtani Közlöny 42, 672-695.

Lóczy L. ifj. 1945: Igazgatói jelentés a Magyar Királyi Földtani Intézet 1943. évi múködéséról. — A Magyar Állami Földtani Intézet Évi Jelentése 1943/I, 1-45.

LovÁsz Gy. \& WeIn Gy. 1974: Délkelet-Dunántúl geológiája és felszínfejlődése. — Baranya monográfia sorozat, Baranya Megyei Tanács, Baranya Megyei Levéltár kiadványa 215 p.

Murray, A. S. \& WintLE, A. G. 2000: Luminescence dating of quartz using an improved single-aliquot regenerative-dose protocol. — Radiation Measurements 32, 57-73. http://dx.doi.org/10.1016/s1350-4487(99)00253-x 
Murray, A. S., Schmidt, E. D., Stevens, T., Buylaert, J.-P., Marković, S. B., Tsukamoto, S. \& Frechen, M. 2014: Dating Middle Pleistocene loess from Stari Slankamen (Vojvodina, Serbia) - Limitations imposed by the saturation behaviour of an elevated temperature IRSL signal. — Catena 117, 34-42. http://dx.doi.org/10.1016/j.catena.2013.06.029

NaGy E. \& NaGy I. 1976: A Villányi-hegység triász képződményei. — Geologica Hungarica series Geologica 17, 111-228.

Novothny Á. \& Úsházy K. 2000: A termo- és optikai lumineszcens kormeghatározás elméleti alapjai és gyakorlati kérdései a negyedidőszaki kutatásokban. — Földrajzi Értesító 49/3-4, 165-187.

Ősi, A., Pozsgai, E., Botfalvai, G., Götz, A. E., Prondvai, E., MakÁdi, L., Hajdu, Zs., Csengôdi, D., Cziruák, G., Sebe, K. \& Szentesi, Z. 2013: First report of Triassic vertebrate assemblages from the Villány Hills (Southern Hungary). — Central European Geology 56/4, 297-335. http://dx.doi.org/10.1556/ceugeol.56.2013.4.2

PAZONYI P. 2009: A Kárpát-medence felső-pliocén és kvarter emlősfauna közösségeinek paleoökológiai vizsgálata. — Földtani Közlöny 139/3, 283-304.

PAZONyi P., MÉszÁros L., Szentesi Z., Gasparik M. \& ViráG A. 2013: A Somssich-hegy 2-es lelőhely gerinces faunájának új kutatási eredményei. - In: Bosnakoff M., Dulai A., Vörös A. \& PÁlfy J. (szerk.): 16. Magyar Ốslénytani Vándorgyúlés, Orfúu. Program, elöadáskivonatok, kirándulásvezetô. Magyarhoni Földtani Társulat, Budapest, 30-31.

PetriK A. 2009: A villányi-hegységi mezozoos képződmények mikrotektonikai méréseinek értelmezése. — Földtani Közlöny 139/3, 217-236.

PIKIJA, M., ŠIKIĆ, K., SARKotić-ŠLAT, M. \& MaGAŠ, N. 1995: Geologija hrvatskog dijela Baranje [Baranya horvátországi részének földtana]. - Proceedings of the First Croatian Geological Congress, Opatija, 18-21/10/1995, Zagreb, 447-451.

Pozsgai, E., Józsa, S., Dunkl, I., Sebe, K., Thamó-Bozsó, E., SAjó, I., Dezső, J. \& von Eynatten, H. (in press): Provenance of the Upper Triassic siliciclastics of the Mecsek Mountains and Villány Hills (Pannonian Basin, Hungary): constraints to the Early Mesozoic paleogeography of the Tisza Megaunit. — International Journal of Earth Sciences. http://dx.doi.org/10.1007/s00531-016-1406-0

Prescott, J. R. \& HutTon, J. T. 1994: Cosmic ray contribution to dose rates for luminescence and ESR dating: large depth and long-term time variations. — Radiation Measurements 23, 497-500. http://dx.doi.org/10.1016/1350-4487(94)90086-8

RAKUSZ Gy. \& Strausz L. 1953: A Villányi-hegység földtana. — A Magyar Állami Földtani Intézet Évkönyve 41/2, 3-27.

RÁLISChNé FelgenhaUeR, E. 1985: Villányi-hegység, Villány, Templomhegyi siklóbevágás. —Magyarország geológiai alapszelvényei. Magyar Állami Földtani Intézet, Budapest, 6 p.

RoBERTS, H. 2007: Assessing the effectiveness of the double-SAR protocol in isolating a luminescence signal dominated by quartz. Radiation Measurements 42, 1627-1636. http://dx.doi.org/10.1016/j.radmeas.2007.09.010

Schmidt, E. D., Machalett, B., Markovic, S. B., Tsukamoto, S. \& Frechen, M. 2010: Luminescence chronology of the upper part of the Stari Slankamen loess sequence (Vojvodina, Serbia). — Quaternary Geochronology 5, 137-142. http://dx.doi.org/10.1016/ j.quageo.2009.09.006

Sebe, K., Pazonyi, P., Gasparik, M. \& Szujó, G. L. 2014: A Villányi-hegység emelkedéstörténete őslénytani adatok alapján. — 17. Magyar Őslénytani Vándorgyúlés, Györ. Program, elóadáskivonatok, kirándulásvezetố. Magyarhoni Földtani Társulat, Budapest, 31-32.

SZABó P. 1957: A klasszikus villányi szelvény üledékföldtani újravizsgálata. — Szakdolgozat, ELTE, Budapest.

SZENTESI, Z. 2016: Urodeles from the Lower Pleistocene Somssich Hill 2 palaeovertebrate locality (Villány Hills, Hungary). — Földtani Közlöny 146/1, 37-46.

Thiel, C., Buylaert, J. P., Murray, A., Terhorst, B., Hofer, I., Tsukamoto, S. \& Frechen, M. 2011: Luminescence dating of the Stratzing loess profile (Austria), — Testing the potential of an elevated temperature post-IR IRSL protocol — Quaternary International 234, 23-31. http://dx.doi.org/10.1016/j.quaint.2010.05.018

Thomasen, K. J., Murray, A. S., Jain, M. \& Bøtter-Jensen, L. 2008: Laboratory fading rates of various luminescence signals from feldspar-rich sediment extracts. — Radiation Measurements 43, 1474-1486. http://dx.doi.org/10.1016/j.radmeas.2008.06.002

Timár, G., BiszaK, S., SzÉKely, B. \& Molnár, G. 2011: Digitized Maps of the Habsburg Military Surveys: Overview of the Project of ARCANUM Ltd. (Hungary). - In: Jobst, M. (ed.): Preservation in digital cartography. Lecture Notes in Geoinformation and Cartography, Springer, Berlin-Heidelberg, 273-283. http://dx.doi.org/10.1007/978-3-642-12733-5_14

Újvári, G., Molnár, M., Novothny, Á., PÁll-Gergely, B., Kovács, J. \& VÁrhegyi, A. 2014: AMS 14C and OSL/IRSL dating of the Dunaszekcsó loess sequence (Hungary): chronology for 20 to $150 \mathrm{ka}$ and implications for establishing reliable age-depth models for the last $40 \mathrm{ka}$. - Quaternary Science Reviews 106, 140-154. http://dx.doi.org/10.1016/j.quascirev.2014.06.009

VADÁsz E. 1960: Magyarország földtana. — Akadémiai Kiadó, Budapest, 646 p.

VöRös A. 1990: Villányi-hegység, Villány, Templom-hegy, felső kőfejtő. — Magyarország geológiai alapszelvényei, Magyar Állami Földtani Intézet, Budapest, $6 \mathrm{p}$.

VÖRÖs A. 2010: A villányi mezozoos rétegsor: visszatekintés új nézőpontból. — Földtani Közlöny 140/1, 3-30.

WintLE, A. G. \& MuRRAY, A. S. 2006: A review of quartz optically stimulated luminescence characteristics and their relevance in singlealiquot regeneration dating protocols. — Radiation Measurements 41/4, 369-391. http://dx.doi.org/10.1016/j.radmeas.2005.11.001

Kézirat beérkezett: 2016. 06. 07. 